Nagy Károly Zsolt

\title{
A kulturális antropológiai terepmunka módszertana
}

DOI: $10.54742 /$ tabula.2019.1-2.01

\section{Bevezető}

1.

A kulturális antropológiai vagy etnográfiai [1] terepról, illetve terepmunkáról meglehetősen nehéz írni. Egyrészt azért, mert az antropológiának ez a legnépszerúbb és „legromantikusabb” része, s ebből következően a fogalmat számos közhely terheli, még a kezdő antropológia szakos hallgatók fejében is. Az antropológus ahogy a filmekből ismerjük - egy valahol Indiana Jones és Teréz anya közt pozícionálható figura, aki általában látványosan fittyet hány a nyugati civilizáció konvencióira, egzotikus helyeken jár és furcsa szokásokat vesz fel. Többnyire nem itt van, hanem távol, valami idegen helyen, $s$ ha itt van, akkor is úgy fest, mint ha nem itt lenne [2]. Nehéz a téma másfelól azért is, mert hatalmas a szakirodalma, és ez a korpusz örvendetes módon magyar nyelven is egyre nagyobb ütemben bövül [3] így azután meglehetősen csekély annak az esélye, hogy az egész korpuszt át tudjuk tekinteni, nem is beszélve annak rendszerezéséról. Végül azért is nehéz a téma, mert az előbbiek következtében az ember nehezen tudja elkerülni, hogy ne valami hatalmas közhellyel kezdje a mondandóját. Akár azt mondom, hogy a terep teszi az etnográfust, vagy hogy a terepmunka fogalma által hivatkozott elméletek és módszertanok adják azt a sajátosságot, ami az etnográfiát a többi társadalomtudománytól megkülönbözteti, akár Clifford Geertz-cel azt, hogy a terepmunka, ez a Malinowski által felépített büszke torony ledőlt, vagy legalábbis repedezik, nem mondok semmi újat vagy eredetit - így hát inkább nem is kísérletezem ezzel, hanem arra mutatok rá, hogy amikor az antropológiai terepmunkáról általánosságban beszélünk, akkor ezeknek az előbbi „akármiknek” az összefüggésében érdemes ezt tennünk. Vagyis látnunk kell, hogy ez alapvető sajátossága az antropológiának, ugyanakkor az is észrevehető, hogy kivált az utóbbi években elég nagy változások mentek végbe a terepmunka terén, ami a klasszikus modell felól kétségtelenül valamiféle válságnak néz ki.

\section{A kultúra fogalma az antropológia mögött}

2.

Feladatom az, hogy az antropológia - első sorban klasszikus - módszertanáról írjak átfogóan. Ahogy minden tudomány, úgy az antropológia esetében is az a helyzet, hogy a módszertan attól függ, hogy a tudomány múvelői mit gondolnak saját tudományuk tárgyáról, és ezzel függ össze, ebből következik az is, hogy miként gondolják azt kutathatónak. Magyarán: amikor a terepmunkával mint a kulturális antropológia módszertanával kívánunk foglalkozni, akkor először arra kell rákérdeznünk, hogy mit gondolnak az antropológusok, etnográfusok a kultúráról, és azok a válaszok, melyeket ezekre a kérdésekre kapunk, egy-egy antropológiai irányzat esetében jó eséllyel elvezetnek a lehetséges módszertanokhoz. 
3.

Már itt fontos leszögeznünk azonban, hogy antropológiáról és módszertanról csak többes számban beszélhetünk. Jóllehet van néhány alapelv - ezekről később bővebben lesz szó - melyek általában jellemzőek az antropológia irányzataira, ám ezekből módszertani tekintetben leginkább csak annyi következik, hogy mindegyik valamilyen etnográfiai gyakorlatot követ, ugyanakkor azt tapasztaljuk, hogy „a legtöbb kutatónak sajátos, egyedi viszonya van a terepmunkához” (Balogh 2017: 10). Ezen a ponton pedig akár máris reménytelennek túnhet a vállalkozásunk, hiszen Kroeber és Kluckhohn egy közös tanulmányában 1952-ben százhatvannégy kultúradefiníciót sorolt fel (Kroeber - Kluckhohn 1952), és az új elméletek megjelenésével, illetve a szakirodalom növekedésével az elmúlt évtizedekben számuk valószínúleg jócskán megemelkedett. A szerzők a kultúra általuk vizsgált definícióit összesen hét kategóriába sorolták, ezek: deskriptív, történeti, normatív, pszichológiai, strukturális, genetikus (vagyis azok a definíciók, melyek első sorban az eredete felől közelítik meg a kultúrát) és „nem teljes” definíciók. Ez utóbbi kategóriába azok a meghatározások tartoznak, melyek vagy metaforikusak, vagy a kultúra szisztematikus meghatározása helyett azt írják le, hogy milyen szempontok mentén lehet válaszolni arra a kérdésre, hogy egy adott társadalom összefüggésében mit nevezhetünk kultúrának. A jelen tanulmánynak sem a keretei, sem a célja nem teszi lehetővé, hogy a Kroeber és Kluckhohn által felállított kategóriarendszer reprezentatív elemeit sorra vegyük, így a következőkben mindössze négy olyan kultúrameghatározást illetve -koncepciót emelek ki, melyeket az antropológiai terepmunka összefüggésében, annak elsősorban a tanulmányomban felvázolni szándékozott változásai tekintetében jellemzőnek tekinthetünk [4].

2.1. A 19. század végén egy darabig az antropológiát Angliában „Tylor úr tudományának" hívták. Tylor úr, azaz Edward Burnett Tylor [5] az első teljes értékü, vagyis a diszciplína minden ágában járatos antropológus, kultúradefiníciója pedig az a „kályha”, melyhez az antropológusok „minduntalan visszatérnek akkor, amikor egyéb definíciók túl nehézkesnek bizonyulnak.” (Bohannan - Glazer 1997:106) Tylor a főmüvének tekintett, 1871-ben megjelent Primitív kultúra címü könyve elején található meghatározása szerint „a kultúra vagy civilizáció szélesebb etnográfiai értelemben az az összetett egész, amely magában foglalja mindazt a tudást, hiedelmet, művészeteket, morál(oka)t, jogot és szokást, és minden olyan emberi képességet és habitust, amire az ember a társadalom tagjaként tesz szert." (Tylor 1920:1.) Tylor definíciója Kroeber és Kluckhohn első, deskriptív kategóriájának alapesete, melybe olyan kultúradefiníciók tartoznak, amelyek - többnyire épp Tylor hatását tükrözve - meglehetősen tágak, és céljuk a kultúra tartalmának számbavétele, vagy pontosabban az ezt lehetővé tevő kategóriarendszer felállítása. Az ilyen definíciókat az idők során sok kritika érte. Ezek egyik részét éppen tágasságuk váltotta ki, hiszen „puttony jellegük” miatt nehezen teszik lehetővé a kultúra elkülönítését attól, ami nem az. A kritikák másik része a tylori koncepció fókuszára vonatkozott: Tylor ugyanis a kultúra meghatározásakor az azt megvalósító emberre helyezi a hangsúlyt, arra, amit az ember a társadalom tagjaként tesz, s ebből következtet arra, hogy mi volt az, amire az ember a társadalom tagjaként tett szert. A megfigyelő tehát csak azt látja, ami az emberek cselekvésein keresztül megnyilvánul, ez pedig nem fedi le és nem is meríti ki teljes mértékben a kultúrát.

Témánk szempontjából ugyanakkor Tylor meghatározásának legalább két fontos implikációja van. Egyfelől Tylor hitt az emberiség pszichikai egységében. Azt val- 
lotta, hogy az emberi elme kultúrától és élőhelytől függetlenül a világon mindenhol alapvetően hasonló, s ez a gyarmatbirodalmak fénykorában, amikor az egyik embercsoport alávetettségét a másikkal szemben hangsúlyozni meglehetősen általános szokás volt, nem magától értetődő álláspont. Az egység ezen elgondolása mögött - másfelől - Tylor evolucionista szemlélete áll: az ok-okozatiság müködésének egyetemes elvét szeretné leírni a kultúra olyan tudománya segítségévvel, mely a természettudományokhoz hasonlít. Ebben a törekvésben az okok és okozatok hatásmechanizmusa, az, hogy ezek alapján egy-egy társadalom a fejlődés mely fokán áll és mely más társadalmakhoz hasonlít, számára fontosabb, mint az, hogy az egymáshoz hasonlított társadalmak tagjai a bőrük színe vagy egyéb külső jellegzetességeik alapján történetesen különbözőek. Az összehasonlító elemzés során egy átfogó kategóriarendszert állít fel - ezeket a kategóriákat nevezi meg a kultúradefiníciójában - majd ezeket alkategóriákra bontva egy olyan egyetemes osztályozási rendszerhez jut, melybe minden kultúra minden eleme egyértelmúen besorolható, és a különböző kultúrákból származó elemek azután a kategórián belül állíthatók fejlődési rendbe.

6.

Ez a puttony-típusú definíció tehát a kultúra teljes lejegyzésének - pozitivizmussal rokon - attitűdjét jelzi, s ezek után nem is meglepő, hogy a terepmunka kortárs fogalma, illetve gyakorlata a kultúra minél teljesebb, rendszerező felgyưjtésének tevékenységet jelenti, eredménye pedig egy szinte katalógusszekrény-szerűen rendszerezett kép az adott kultúráról. Ennek a szemléletnek kiváló dokumentuma a British Association for the Advancement of Science [6] által Notes and Queries on Anthropology címen 1874-ben kiadott adatgyüjtési ajánlás (BAAS 1874), melynek kidolgozásában Tylornak is fontos szerepe volt. Az ajánlás alcíme szerint a civilizálatlan vidékeken élők és utazók számára [7] készült, s valóban, elsődleges célközönségét nem az elméletalkotó „tudósok”, hanem az utazók és más antropológiai megfigyelők - a gyakorlatban például misszionáriusok és gyarmati tisztviselők - alkották. Célja pedig az volt, hogy számukra, akik maguk ugyan nem antropológusok, minél hathatósabb támogatást nyújtson, hogy minél pontosabb antropológiai megfigyelésekkel lássák el azokat, akik otthon az antropológia tanulmányozásával foglalatoskodnak (BAAS 1874:IV). A kérdőívnek ez az első verziója a brit antropológiai szemlélet szerinti felosztásban, egy fizikai és egy kulturális antropológiai - valamint egy rövidke „egyebek” - tematikájú nagy fejezetben összesen száz tematikus alfejezetet, és ezekben mintegy 2600 kérdést tartalmazott []ㅡ. Ezt a sztenderdizált kérdőívet jobbára bárki ki tudta tölteni, nem igényelt különös szaktudást, mégis hozzájuttatta a tudósokat a legfontosabbnak tekintett, és különböző kultúrák összehasonlítását lehetővé tevő adatokhoz [9]. A Notes and Queries azonban a későbbiekben a professzionális terepmunkára is jelentős hatást gyakorolt, noha ebben a kontextusban célja némiképp változott. Az 1951-ben megjelenő hatodik kiadás előszavában a szerkesztők már a könyv kettős céljáról írnak: ez egyrészt az, hogy „terepmunkájuk során az emlékezet segítője legyen a képzett antropológusok számára, illetve alapos megfigyelésre és információrögzítésre sarkalljon bárkit, aki olyan emberekkel és kultúrákkal kerül kapcsolatba, melyeket ezidáig nem írtak le teljesen" (Seligman 1951:27). Miután pedig egyetlen kultúrát sem írtak le ezidáig kimerítően - jegyzi meg a szerző - bárki találhat magának megfigyelni valót bármilyen területen, ahol éppen jár. Ezt követően az előszó hosszasan hangsúlyozza, hogy „minden antropológiai kutatásban lényeges, hogy tisztán különbséget tudjunk tenni a megfigyelés és az interpretáció között. A feljegyzésekben és beszámolókban nem szabad összekeverni az elméleteket és a tényeket. A megfigyelő, aki az anyagához elméletet akar gyártani, ezzel csak a tények 
rögzítése után foglalkozhat” (Seligman 1951:27). A megfigyelőnek azonban nem csupán azokkal az elméletekkel kell óvatosan bánni, melyeket ő alkot, hanem azokkal is, melyek őt alkotják. Mindannyiunkat befolyásolnak ugyanis az „otthonról hozott” beidegződések, a természetességről és rendellenességről alkotott, és a saját kulturális környezetünk által belénk nevelt előítéletek. A képzett és az amatőr kutatót pedig pontosan az különbözteti meg, hogy az előbbi képes arra, hogy ezeket tudatosítsa magában, míg az utóbbi - nem lévén erre kiképezve - gyakran helyezi megfigyeléseit a saját kultúrája által sugalmazott, téves értelmezési keretekbe.

A Notes and Queries jól tükrözi azt a brit szociálantropológiai hagyományban megjelenő - de különböző formában más területeken is jelenlevő [10] - megkülönböztetést, mely elválasztja egymástól a terepen mozgó megfigyelőt és az elméletalkotót. Az előbbi az etnográfus, az utóbbi az antropológus, az elóbbi tevékenységének fókuszában a megfigyelés és leírás (graphein) áll, míg az utóbbi a megfigyelések eredményeiból alkot általános elméleteket (logein). Az etnográfus itt alapvetően az a - nem feltétlenül szakirányú végzettséggel rendelkező - személy, aki ellátja a távoli népekre vonatkozó adatokkal az otthon, karosszékében elméleteket alkotó tudósokat. Az etnográfusok azonban nem csak adatokat, hanem tárgyakat - és egyre nagyobb számban fényképeket - is gyüjtöttek és küldtek megrendelőiknek vagy megbízóiknak. Ezek a nagyon eltérő helyről származó, majd múzeumokban vagy különböző gyüjteményekben egymás mellé kerülő anyagok nem csupán a feldolgozás - többé-kevésbé azonos szempontú leírás és katalogizálás - szintjén szolgáltattak fontos adatokat az evolucionista összehasonlító elemzések számára, hanem a bemutatáson keresztül a szakmain túl a szélesebb közönség előtt is érzékletesen demonstrálták a kultúrák „fejlődését” és ezen keresztül a modern nyugati civilizáció fölényét, illetve legitimálták „primátusát” [11]. Az a gyưjtő, megmentő, rendszerező attitűd, mely az etnográfiát - ebben a tekintetben mint a múzeumi és egyéb reprezentációs formákig kiterjesztett tevékenységet - a kezdetektől jellemezte, ebben az identitáskonstrukcióban betöltött funkcióban nyeri el végső értelmét.

8.

2.2. Az evolucionista gondolkodással szemben a Franz Boas nevéhez kötődő történeti partikularizmus egyrészt a kultúrák egyediségét és egyenlőségét, és ebből következően azt hangsúlyozza, hogy azok nem rendezhetők különböző fejlődési sorokba, másrészt azt állítja, hogy a maguk egyediségében, a saját történetük perspektívájában tanulmányozott kultúrák, mint egyenlő értékkel bíró entitások hasonlíthatók egymással össze. Boas tehát - akire a tudománytörténet úgy tekint, mint akinek munkássága jelentős mértékben hozzájárult ahhoz, hogy az antropológia érett tudománnyá váljék az Egyesült Államokban - az antropológia módszertanának alapvető meghatározójaként az indukció elvét jelölte meg. A kutatást mindig egy jól körülhatárolt, kis földrajzi területre szúkítve tartja elkezdhetőnek, $\mathrm{s}$ ezen belül vizsgálja a különböző kulturális jelenségek kialakulását. Az evolucionista módszerrel szemben a különböző földrajzi területeken jelentkező, látszólag hasonló jelenségeket nem vezeti vissza automatikusan ugyanazokra az okokra, illetve körülményekre, hanem azt állítja, hogy „minél egyszerübb a megfigyelt tény, annál valószínúbb, hogy a különböző helyeken különböző eredőkből fejlődött ki” (Bohannan - Glazer 1997:140). Éppen ezért, mint írja, „követelménnyé kell tennünk az okok vizsgálatát, amelyekből a jelenség kifejlődött, és hogy az összehasonlítás csak azokra a jelenségekre korlátozódjon, amelyekről bebizonyosodott, hogy 
ugyanazoknak az okoknak az okozatai. [...] Röviden: mielőtt átfogó összehasonlításba kezdünk, be kell bizonyítanunk az anyag összehasonlíthatóságát” (Bohannan - Glazer 1997:140). Csak ennek az aprólékos módszernek a konzekvens, egyegy földrajzi területre - és azon belül egy-egy önálló kultúrára - történő alkalmazása révén juthatunk Boas szerint megalapozott állításokhoz. „Amikor kibogozzuk egy kultúra történetét és megértjük a környezeti hatásokat, valamint a pszichológiai adottságokat, amelyek abban tükröződnek, egy lépést tettünk előre, hiszen ezután megvizsgálhatjuk, hogy ugyanezek vagy más okok mennyiben játszottak szerepet más kultúrák kifejlődésében. Így a fejlődéstörténeteket összehasonlítva általános törvényekre is lelhetünk. [...] csak akkor remélhető, hogy az összehasonlító módszer eléri azokat a nagyszabású eredményeket, amelyekre törekszik, ha vizsgálatait a minden egyes kultúra komplex kapcsolatainak tisztázását célzó kutatások történeti eredményire alapozza" (Bohannan - Glazer 1997:144-145).

9.

Boas átfogó, rendszerszerú érdeklődése nem csupán ebben a longitudinális, történeti szemléletben mutatkozott meg, hanem abban is, ahogy a kultúrát, mint „komplex egészet” szemlélte. Mint arra elemzésében George W. Stocking rámutat (Stocking 1966), Boas kultúrafogalma kezdetben gyakorlatilag nem különbözik Tylor kultúrafogalmától, vagyis a kortárs humanista illetve evolucionista gondolkodás keretein belül maradt, idővel azonban túllépett ezen [12]. Szóhasználata például a kultúra és a civilizáció fogalmának szintén öröklött párhuzamossága sokáig konfúz és ingadozó, az 1910-es évek elejére azonban, ahogy kidolgozta az evolucionista elmélettel kapcsolatos kritikáját, úgy használta egyre következetesebben - például egyre tudatosabban többes számban - a kultúra fogalmát [13]. 10.

1930-ban azután, mintegy összegezve tapasztalatait egy társadalomtudományi enciklopédia Antropológia címszavában a következő kultúradefiníciót adja: „a kultúra magába foglalja egy közösség társadalmi szokásainak minden megnyilvánulását, az egyén reakcióit, ahogyan azokra a csoportnak, melyben él, a szokásai kihatnak, és az emberi tevékenységek eredményeit, úgy, ahogyan ezeket a fenti szokások meghatározzák" (Boas 1930:79). Majd később, a kultúra integrációjával kapcsolatosan hozzáteszi: ,az emberlét különböző aspektusainak összessége: a testi jellegzetességek, a nyelv, a kultúra, csakúgy mint a környezet, melyben elhelyezkedik, egymással szoros összefüggésben áll, a kultúra formája pedig ennek az integrációnak az eredménye." (Uo.: 98) 1938-ban a The Mind of Primitive Man revideált kiadásában Boas jelentősen kitágította és pontosította is ezt a definíciót. A módosított verzió szerint ,a kultúra meghatározható úgy, mint azon mentális és fizikai reakciók és aktivitások összessége, melyek egy társadalmi csoportot alkotó egyének viselkedését a természeti környezetükkel, más csoportokkal, a saját csoportjuk tagjaival és minden egyes individuumot önmagával összefüggésben, kollektíve és individuálisan is jellemeznek. A kultúra szintén magába foglalja ezeknek az aktivitásoknak az eredményeit, és azoknak a csoport életében játszott szerepét. Az élet e különböző aspektusainak puszta felsorolásával azonban még nem határoztuk meg a kultúrát. Az ugyanis, mivel elemei nem függetlenek egymástól, hanem struktúrájuk van, ennél több. Azok a tevékenységek, melyeket itt felsoroltunk, semmilyen értelemben sem képezik kizárólag az ember tulajdonát, hiszen az állatok életét éppígy a természettel, más állatokkal és azon más egyedekkel való kapcsolatuk szabályozza, melyekkel egyazon fajhoz vagy társas csoportszerveződéshez tartoznak" (Boas 1938:159). Ezt követően hosszan részletezi, hogy melyek is azok a tevékenységek, amelyek a kultúrát alkotják, majd a definícióban megelőlegezett állítást kifejtve arra mutat rá, hogy ezek többsége az állati társadalmakban 
is megtalálható. Mi különbözteti meg akkor mégis az embert az állattól, miben más a kultúra és az állati viselkedés? Boas szerint az állat sztereotipizáltan, ösztönösen viselkedik, amit tesz, az nem tanult és csak nagyon csekély változatosságot mutat, és egyáltalán nem függ a helyi hagyományoktól. Ezzel szemben az ember kulturális viselkedése nem ösztönös vagy sztereotipizált, hanem minden esetben tanult, és a helyi hagyományok által meghatározott. Ezen felül Boas szerint az állatok nem képesek retrospektíve értelmezni cselekedeteiket. A kauzalitás problémája és az a kérdés, hogy miért történnek meg egyes dolgok, szerinte tökéletesen idegen az állatvilágtól, míg az ember érvelő-értelemkereső lény, s ezt az értelemkeresést egészíti ki a nyelvhasználat, valamint az a sajátosság, hogy a cselekedeteket etikai és esztétikai szempontból is értékeli (lásd Boas 1938:159-164).

Boast tehát elsősorban ez a komplex, helyi hagyományokba ágyazott értelemkereső emberi tevékenység érdekli, ami a kultúra interakcióinak rendszerében nyilvánul meg. Számára minden ennek az interakciós rendszernek a része, és ebból a nézőpontból is értelmez mindent. Tylorral szemben például, aki a folklórt olyan jelenségek halmazának tekintette, melyek eredetüket tekintve racionális indokkal bírtak, de úgy maradtak fent, mint irracionális szokások, Boas úgy tekintett a folklórjelenségekre, mint amelyek eredetüket tekintve nem tudatosak, ám a társadalom számára a tradicionális viselkedési formák racionalizációjának eszközeként központi jelentőségűek (Stocking 1966:878).

Ezek alapján már érthető, hogy Boas terepmunkáin az általa kutatott kultúrák minél mélyebb és átfogóbb megértésére törekedett. Széles múveltségü és sokoldalúan képzett kutató volt. 1881-ben Kielben fizikából - a víz színét befolyásoló tényezók megértésével kapcsolatos disszertációval - szerzett doktori fokozatot, ám alapvetően a geográfia érdekelte, amint témavezetője, Theobald Fischer is geográfus volt. Boast alapvetően az foglalkoztatta, hogy a különböző intenzitású fények hogyan okoznak különböző színészleléseket, amikor különböző típusú vizekkel lépnek interakcióba, ám a megfigyelések pontosságával és azok nyelvi kifejezésének lehetőségeivel folyamatosan problémája volt. Ezek a kérdések, és esztétikai tanulmányai során a kanti filozófia iránt ébredt érdeklődése fordították az akkor nagy népszerüségnek örvendő pszichofizika irányába, és ezek mentén tervezte meg első terepmunkáját a Kanada északkeleti partvidékénél húzódó Baffin-szigetekre. Az expedíció célja a terület topográfiai felmérése volt. Fontos azonban, hogy tudományos kontextusát egyrészt Boas előbb említett problémái, másrészt a német földrajztudomány kortárs vitái jelentették, melyeknek egyik fontos kérdése az volt, hogy az emberi kultúrák változatosságában meghatározó tényezőnek a fizikai környezetet vagy az emberi populációkkal együtt vándorló tudásokat, szellemi javakat kell-e tekinteni? Ebben az összefüggésben tehát Boas számára a geográfia az ember szubjektív tapasztalata és az ôt körülvevő objektív világ közötti kapcsolat tanulmányozásának eszköze volt, és a terület feltérképezése számára azért volt fontos, hogy az inuitok jelenlegi élőhelyükre való betelepülésének összefüggésében vizsgálja a fizikai környezet jelentőségét (Krober 1943; Lowie 1947; Williams 1998; Harris 2001:250-289; Bakos 2015). 13.

A mostoha éghajlati körülmények nem kedveztek a kutatásnak, és Boas talán életben sem maradt volna, ha az ott élő inuitok be nem fogadják, és meg nem tanítják a túlélés szabályaira. Ennek a tanulási folyamatnak a következtében fordult Boas érdeklődése egyre inkább a tér szimbolikus jelentősége felé. Boas megfigyelte azt 
is, hogy az inuitoknak sokkal több szavuk volt a fehér színre, mint az európaiaknak, mivel a hó különböző halmazállapotai más és más jelentéssel bírtak számukra. Ezen keresztül pedig azt is felismerte, hogy a nyelv a kultúra egyik legfontosabb közvetítője, amelynek segítségével az egyes népcsoportok az identitásukat is képesek megfogalmazni a maguk számára (Vörös-Frida 2006: 404-405). A terepmunkát követően Boas visszatért Berlinbe, hogy befejezze tanulmányait, s közben az Ethnologisches Museumban dolgozott, ahol 1886-ban egy Brit-Kolumbiából érkező Nuxalk tánccsoporttal találkozott. Boas a nagy maszkokkal mozgó táncosok előadásában az idegen kultúra egészének megmutatkozását fedezte fel, s ez az élmény meghatározó lett számára: egyrészt egy rövid brit-kolumbiai tanulmányútra indulva végül az Egyesült Államokban maradt, másrészt munkásságának jelentős részét Amerika nyugati-parti bennszülöttei kultúrájának tanulmányozása tette ki.

14.

Boas 1888-ban publikálta első szövegét a kwakiutl indiánok között a tánc és a kultúra összefüggéseiről folytatott kutatásairól, s ez az érdeklődés egész életét végigkísérte. A táncot nem az individuum, hanem a közösség felől közelítette meg. A kutatás fontosságát, értelmét utolsó publikált írásában világította meg. Mint írja: „az előbbiekből látható, hogy a kwakiutl élet minden eseményét ének és tánc kíséri, s így ezek lényegi részét képezik kultúrájuknak. Az ének és a tánc itt elválaszthatatlanok. Jóllehet vannak képzett előadók, az éneklésben és a táncban való részvétel mégis mindenki számára kötelező, így az a különbségtétel, melyet előadók és hallgatóság közt saját, modern társadalmunkban megtalálunk, az olyan primitív társadalmakban, melyek a kwakiutl indiánokéhoz hasonlóak, nem fordul elő.” (Idézi Ruby 1980: 9) Boas azonban nem csupán a tánc, hanem a közösség összes testtechnikája, a mindennapi mozgás, és a kultúra összefüggéseit vizsgálta. Miközben úgy tekintett a táncra, mint a táncos emocionális és esztétikai önkifejezésére, mégsem a tánc individuális karakterére, hanem sokkal inkább társadalmi beágyazottságára figyelt s a táncot a kultúra kifejeződésének tartotta. A tánc szerinte éppen úgy, mint a mindennapi jövés-menés és az ún. motorikus mozgások, egyaránt arra szolgálnak, hogy jelezzék az individuum kulturális identitását, s mint ilyenek alávethetők az etnográfiai leírásnak és analízisnek. Ehhez azonban megfelelő eszközöket kellett találni, s ez vezette el Boast a filmhez. Állóképeket gyakorlatilag kutatásai során mindig készített, ám mozgófilmes kamerát először utolsó terepmunkájára, 1930-ban vitt magával. Ekkor hetven esztendős volt. kwakiutl táncokat filmezett, s a képi rögzítéssel párhuzamosan hangfelvételt is készített. A kamerát maga kezelte. A Boas filmes tevékenységével foglalkozó Jay Ruby egyértelmüen kimutatta (Ruby 1980), hogy Boas felvételei a mozgás tanulmányozásának céljával készültek, s feltételezte, hogy célja egy, a mozgás leírására szolgáló módszer kifejlesztése volt, aminek alapját az akkor nagyon friss, Lábán-féle táncjelírásnak a táncon túl, a mozgás teljes spektrumára történő kiterjesztése jelentette volna. Fontos ugyanakkor, hogy a tánc megértésében Boas nem kizárólag a filmre akart hagyatkozni. A filmfelvételt hangrögzítés kísérte, ám ez nem hangosfilmet eredményezett, hiszen technikai okokból a kép és a hang igazából sosem került szinkronba. A hangrögzítés értelme az információcsatornák megtöbbszörözése volt, ahogyan ezt a célt szolgálták az állóképek, a szöveges jegyzetek és vázlatrajzok, illetve az is, hogy Boas megkérte asszisztensét, hogy tanulja meg a táncokat. 15 .

Boas tehát belülről próbálta megismerni a kultúrát, a bennszülött értelemadás perspektívájából, ezért nagy hangsúlyt fektetett a terepmunkára. A kultúrát totali- 
tásként, rendszerként szemlélte, ugyanakkor munkájának hátterében az az elképzelés állt, hogy az így megismert kultúrák mégiscsak összehasonlíthatóak, rendszerbe állíthatóak, s így megtudhatunk arról valamit, hogy egy-egy szokás vagy társadalmi intézmény hogyan alakult ki.

16.

2.3. Ezt az elképzelést azonban többen, így a Boasnál huszonhat évvel fiatalabb, de vele egy esztendőben, 1942-ben elhunyt Bronislaw Malinowski sem osztotta. Mindkét kutató munkásságában központi szerepe volt a terepmunkának, ami mindkettőjük esetében nagyon aprólékos, körültekintő és a vizsgált társadalom lehető legszélesebb spektrumában végzett adatgyưjtést és az adatok kontextuális elemzését jelentette. Ezen túl az is elmondható, hogy kultúrafogalmaik alapjában véve szintén nem álltak nagyon távol egymástól. Malinowski 1931-ben ugyanabban az enciklopédiában, melyból Boast fentebb idéztem, a Kultúra címszóban a kultúra szót az embereket egymástól megkülönböztető társadalmi örökség szinonimájaként használta. Ez a társadalmi örökség - mely szerinte a kulturális antropológia kulcsfogalma - alapvetően az öröklött alkotásokból, javakból, technikai eljárásokból, eszmékből, szokásokból és értékekből tevődik össze. A társadalmi szerveződés különböző formái pedig nem érthetők meg másként, csak mint ennek az örökségnek a részei (Malinowski 1931:621).

E hasonlóságok ellenére azonban Boas és Malinowski felfogása meglehetősen távol áll egymástól, s ez abból következik, hogy jóllehet a kultúrát hasonlóan határozzák meg, de kutatásaikban és szemléletükben maga a kultúra más-más szerepet tölt be (lásd Helm 2001; Dianteill 2012). Emögött pedig egyebek mellett az a különbség áll, ami az amerikai kulturális antropológia és a Malinowski által múvelt szociálantropológia - vagy ahogyan akkortájt nevezték: empirikus szociológia között van. Malinowski saját magát az empirikus szociológián belül is a funkcionalista irányzathoz sorolta. A funkcionalisták szerint pedig egy szokás értelmezése során nem az az alapvető kérdés, hogy az miként alakult ki, hanem az, hogy itt és most hogyan múködik, milyen szerepet játszik a társadalmi integrációban (Kisdi 2012:104). Malinowski ezt a szerepet viszonylag egyszerüen megfogalmazva abban látja, hogy a kultúra „egy hatalmas instrumentális realitás - eszközök és javak, társadalomszervezeti irányelvek, eszmék és szokások, hiedelmek és értékek együttese -, amelyek összessége lehetővé teszi az ember számára, hogy kielégítse biológiai szükségleteit, mégpedig együttmúködés révén, egy átalakított és igényeihez igazított környezetben. Az emberi szervezet azonban e folyamat során maga is módosul, s hozzáidomul a kultúra által nyújtott szituációhoz. Ilyen értelemben véve a kultúra maga is roppant nagy kondícionáló apparátus, amely a nevelésen, a jártasságok továbbadásán, az erkölcsök tanításán és az ízlés kifejlesztésén keresztül külsődleges elemeket vegyít az emberi fiziológia és anatómia nyersanyagába, s ezáltal kiegészíti a testi adottságokat és kondicionálja a fiziológiai folyamatokat" (Malinowski 1997:387). A kultúrának tehát az alapvető funkciója az, hogy ezen a módon individuumokat hoz létre. 18.

Malinowskinak ez a meghatározása egy 1939-ben, az American Journal of Sociology társadalmi integrációval foglalkozó tematikus számában megjelent tanulmányából származik, melyet kimondottan azzal a céllal írt, hogy összefoglalja saját „igaz és tiszta” funkcionalizmusát, vagyis a funkcionalizmusnak azt a vállfaját, melyet ő alkotott meg és használ. Ebben a szövegben ugyanúgy egy integrált rendszernek tekinti a kultúrát, mint Boas, viszont „a mentális folyamatoknak nem pusztán emocionális és intellektuális oldalaira figyel, hanem amellett érvel, hogy 
az embert teljes biológiai realitásában kell bevonnunk kulturális elemzésünkbe. A testi szükségleteket és a környezeti hatásokat, s azokra adott válaszokat tehát egymás mellett kell tanulmányoznunk" (Malinowski 1997:380). Malinowski ugyanakkor a funkcionalizmus más irányaitól, kivált a szakma által többnyire vetélytársának tekintett A. R. Radcliffe-Browntól is megkülönbözteti magát, hiszen az szerinte „még mindig a francia szociológiai iskola nézeteit fejleszti tovább és mélyíti el. Így kénytelen figyelmen kívül hagyni az egyént és eltekinteni a biológiától” (Malinowski 1997:405). Malinowski viszont éppen ezeket hozza összefüggésbe a társadalom múködésével, s ezt úgy teszi, hogy nem csak az egyénre vagy csak a társadalomra, hanem mindkettőre és a kettő kapcsolatára, kölcsönös függésére koncentrál, melynek megértésében a biológiai szükségletek és a társadalmi megoldások dinamikája lesz számára a kulcs. Ez áll érdeklődésének középpontjában, és ez szervezi, határozza meg a terepmunkáját és az elméletalkotását, a megfigyeléseit és az elemzéseit.

19.

Malinowski számára a kulturális jelenségek és folyamatok totalitását az egyének individuális mentális folyamatai és a társadalomszervezeti formák mellett, ezeket is meghatározó módon az általa ,anyagi apparátusnak” nevezett tényező teszi teljessé. Az anyagi apparátus, vagyis a kulturális folyamatok során elérhető materiális eszközkészlet (felkészültség) vizsgálata „elengedhetetlen annak megértéséhez, hogy egyfelől egy kulturálisan meghatározott individuum hogyan jön létre, másfelől hogy miként múködik együtt más individuumokkal a csoportélet során” (Malinowski 1939:939). A kulturális jelenségek és folyamatok totalitása azonban Malinowski számára nem a vizsgálat elsődleges tárgya, hanem „csupán” az ember és a társadalom elemzéséhez nélkülözhetetlenül szükséges háttér. A vizsgálatot végző terepkutató az embereket ez előtt a háttér előtt, vagyis egy olyan, számukra adott, „természeti és mesterséges környezet keretei között tevékenykedve figyeli meg, amely hatással van rájuk, és amelyet, másfelől, egymással együttmúködve átalakítanak. Azt vizsgálja, hogy a férfiakat és nőket egymás közötti viszonyukban hogyan motiválják a vonzalom, és az ellenszenv érzései, az együttmúködés kötelezettségei és privilégiumai, az abból származó haszon és az azért hozott áldozatok. A társadalmi kötődések láthatatlan hálózatát - amelyekből a csoport szervezet összeáll technikai, jogi, szokásbeli és erkölcsi irányelvek és kódok határozzák meg, amelyeknek az egyes egyének különbözőképp vannak alávetve, és amelyek a csoportot egységes egésszé integrálják. Mivel minden szabályt és minden törzsi hagyományt szavakkal - tehát szimbólumokkal - fejeznek ki, a társadalomszervezet megértésének részét képezi a jelképrendszer és a nyelv elemzése" (Malinowski 1997:380). 20.

Malinowski erre az elméleti alapra építette fel azt a terepmunka módszertant, mely hosszú évtizedekre az antropológiai terepmunka sztenderdje lett. Módszertanát átfogóan az Argonauts of the Western Pacific, vagyis A nyugat-csendes-óceáni térség argonautái című kötetében fejti ki. Számára „az etnográfus varázslata, mellyel képes megidézni a bennszülöttek igazi szellemét és megrajzolni a törzsi lét valódi képét [...] a józan ész és az ismert tudományos alapelvek szabályainak türelmes és rendszeres” alkalmazását jelenti. Munkájában három alapelvet emel ki:

„Először is, a kutatónak ismernie kell a modern etnográfia értékeit és kritériumait, magáévá kell tennie valódi tudományos céljait. Másodszor, munkájához megfelelő körülményeket kell választania, vagyis többnyire más fehér emberektől elválasztottan, a bennszülöttek között kell élnie. Végül, adatainak begyüjtése, rendszerezése és rögzítése során néhány speciális szabályt kell alkalmaznia” (Malinowski 2000:46). 
21.

Az eredetileg matematikusnak készülő Malinowski a természettudományok mintájára az etnográfia megbízhatóságának kritériumát a kutatásmódszertan következetességében, részletes kifejtettségében és átláthatóságában, vagyis egyfajta „módszertani nyíltságban” jelöli meg. Ezt a nyíltságot pedig azért tartja szükségesnek, mert úgy véli, hogy „csak azok az etnográfiai leírások tekinthetők megkérdőjelezhetetlenül tudományos értékűnek, amelyekben világosan megkülönböztethetők egyfelől a közvetlen megfigyelések és a bennszülöttek állításai és értelmezései, másfelől pedig a szerző beavatkozásai, melyek a józan ész alkalmazásán és a 22. pszichológiai meglátás képességén múlnak” (Malinowski 2000:44).

Malinowski számára a terepmunka célja nem az, hogy egy elméleti konstrukcióhoz a kutató néhány példát, illusztrációt gyüjtsön, hanem „a bennszülött nézőpontjának és élethez való viszonyának megragadása, annak érdekében, hogy saját világának saját maga által alkotott képéhez jussunk." (Malinowski 2000: 56) E cél elérése érdekében „a terepen az etnográfus kötelessége, hogy felvázolja a törzsi lét összes szabályát és törvényszerüségét, mindent, ami állandó és változatlan; hogy a kultúra anatómiáját hozza létre, hogy megrajzolja a társadalom felépítését." (Malinowski 2000: 48-49) Ez persze nem egyszerü feladat, hiszen ezeket a dolgokat „bármennyire kikristályosodottak és rögzültek is, sehol sem fogalmazzák meg. Nem létezik írott vagy más explicit módon kinyilvánított törvény, a bennszülöttek összes törzsi hagyománya és társadalmuk egész struktúrája a matériák legképlékenyebbikében, az emberi lényben testesül meg" (Malinowski 2000:48-49). Éppen ezért a terepmunka legfontosabb módszertani eleme a reflexív kutatói jelenlét, aminek mibenlétét Malinowski három „parancsolat” segítségével körvonalazza: 23.

1. „A törzs szervezetét és kultúrájának anatómiáját határozott, világos körvonalakkal kell megrajzolni. Ezt a vázlatot pedig a konkrét statisztikai dokumentáció módszerének segítségével lehet elkészíteni." (Malinowski 2000: 56.) E módszer lényege az, hogy a kutató minden egyes jelenséget, amivel terepmunkája során találkozik, konkrét előfordulásainak a lehető legszélesebb körében vizsgálja, az egyes esetek minden részletre kiterjedő felmérésével. Ez a kutatás kezdeti fázisának elsődleges feladata, de Malinowski figyelmezteti olvasóit, hogy az így felvázolt keretrendszert ne tekintsék változtathatatlannak, hanem az újabb részletek feltárása nyomán folyamatosan korrigálják.

2. Ezt a keretet azután a bennszülöttek mindennapi életében való részvétel során gyüjtött apróbb-nagyobb megfigyelésekkel, a bennszülött „viselkedés típusaival” kell feltölteni. Az adatokat aprólékos és részletes megfigyelések révén, egyfajta etnográfiai terepnapló formájában szükséges begyüjtenünk. Ennek a folyamatnak az alapja az a technika, amit Malinowski múve alapján a szakirodalom résztvevő megfigyelésnek hív, jóllehet Malinowski a részvételt és megfigyelést inkább két, egymást kiegészítő tevékenységként fogalmazza meg. Malinowski itt gyakorlatilag a terepen eltöltött mindennapjainak - mint később nyilvánosságra hozott személyes naplójából [14] kiderült, néha meglehetősen frusztráló, és egészségi állapotának ingadozása miatt megterhelő, hol revelatíve, hol végletesen unalmas - rutinjait, a bennszülöttekkel való kommunikáció nehézségeit és azok áthidalására tett erőfeszítéseit, s nem utolsó sorban az otthontól, megszokott környezetétől távolra szakadt kutatónak azokat a technikáit formálja módszertanná, melyek segítségével ezekkel a helyzetekkel megküzdött. Malinowski például alapvetően nem jószántából töltött el két évet a Trobriand szigeteken, hanem azért, mert terepmunkája 
közben kitört az I. világháború, s ő, mint osztrák-magyar állampolgár, hivatalosan ellenségnek számított. A brit tisztviselők viszont nem zárták gyújtótáborba, hanem a terepen maradhatott. Ez a tapasztalat azonban módszerré transzformálódva jelent meg müvében. Mint írja: „a bennszülött lét bensőséges részletei bemutatásának és ismerőssé tételének képességét [...] csak úgy lehet elsajátítani, ha a kutató, így vagy úgy, de hosszú időn keresztül közeli kapcsolatban marad a bennszülöttekkel. [...] Ha a faluban élve semmi más munkánk nincs, mint a bennszülöttek életének nyomonkövetése, akkor újra meg újra láthatjuk a szokásokat, szertartásokat és tranzakciókat, hiedelmeiket megélt példákon keresztül ragadhatjuk meg, és az igazi bennszülött lét teste és vére egy csapásra kitölti az elvont elméleti konstrukciók csontvázát" (Malinowski 2000:52).

25 .

A „bennszülött nézőpont” elsajátításával kapcsolatosan ezen a ponton érhető tetten leginkább az, amit Malinowski a „pszichológiai meglátás képességén” ért, s amit az empátia és intuíció sajátos elegyeként fogalmaz meg. Mint írja, „a szertartások és más törzsi események megfigyelése során szükségessé válik nemcsak a hagyomány és a szokás által előírt, az esemény lefolytatása szempontjából lényeges történések és részletek lejegyzése, hanem a szertartásban résztvevők és az azt nézők tevékenységeinek gondos és precíz leírása is: úgy, ahogy azok egymást követik. Egy pillanatra [a kutatónak] el kell felejtenie, hogy ismeri és érti ennek a szertartásnak a szerkezetét, illetve az alapját képező legfontosabb dogmatikus elgondolásokat is, és meg kell próbálnia magát emberek között látni, akik komolyan vagy tréfásan, odaadó figyelemmel vagy unott frivolitással tekintenek az eseményekre, akik éppen olyan hangulatban vannak, mint ahogy nap mint nap látja őket vagy a felcsigázott érdeklődés és az izgatottság látszik rajtuk, és így tovább” (Malinowski 2000:54). Az etnográfiai megfigyelés tehát számára egyszerre objektív, leíró tevékenység és intuíció kérdése. A megfigyelést azonban javaslata szerint érdemes néha a részvételre cserélni: „Az ilyenfajta munkában jót tesz az etnográfusnak, ha néha félreteszi a fényképezőgépét, jegyzetfüzetét és ceruzáját, és bekapcsolódik a tevékenységekbe. Részt vehet a bennszülöttek játékaiban, elkísérheti őket sétáikra és amikor vendégségbe mennek, leülhet közéjük, amikor beszélgetnek egymással, figyelmesen hallgathatja ooket és megpróbálhat részt venni a beszélgetésben" (Malinowski 2000:54). 26.

Az efféle tevékenységnek, melyet itt némileg fennkölt megfogalmazással a „bennszülöttek életében való megmártózásnak” nevez, hasznát abban látja, hogy a bennszülöttek jelentéktelennek tűnő tevékenységében való részvétel során szerzett tapasztalatok, a velük megélt valamilyen közösség átláthatóbbá és könnyebben érthetővé tette számára mindazt, amit megfigyelései során rögzített. Odáig azonban, hogy erre az etnográfia módszertana számára alapvető felismerésre eljutott, egy meglehetősen rögös út vezetett, hiszen ennek a „megmerítkezésnek” az alkalmai privát naplójában többnyire a következő leíráshoz hasonlóan festenek: „Ezen a napon a férfiak Gumasiláról és Nu'agasi-ról Boyowára mentek kula cserét folytatni. Valami rejtély vagy babona miatt soha nem lehettem szemtanúja indulásuknak ('́gy volt ez Mailun, Omarakán, és itt is). 9-kor keltem, mint mindig. (Előző nap semmit sem vettem észre. Kipela fürdött és tisztálkodott - vajon menyasszonyához készült utolsó látogatásra, vagy ez a kula része volt?) Gumawanára mentem (utálkozva, de reménykedve). Az asszonyok - mint rendesen - nem mutatkoztak. Néhányukat láttam messziról. De ez nem tévesztett meg. A bwyamába mentem és megfigyeltem, ahogy a cserépedényeket rendezgetik. Semmi más, csak edények, 
sago és nuya. Nem tudtam meggyőzni óket, hogy vegyék ki a bogana sagót. Néhány képet készítettem" (Malinowski 2001:89).

27.

3. Végül Malinowski harmadik parancsolata szerint „az etnográfiai állítások, jellemző narratívák, tipikus kijelentések, folklórelemek és mágikus előírások kollekcióját corpus inscriptioniumként, a bennszülött mentalitás dokumentumgyüjteményeként kell összefoglalnunk" (Malinowski 2000:56), ami azt jelenti, hogy az elemzés során - hiszen a cél az, hogy a bennszülött saját világának a saját maga által alkotott képéhez jussunk el - mindig szó szerint kell felhasználni a bennszülött osztályozás terminusait, úgy, hogy a tudományos - szociológiai, pszichológiai és gazdasági - terminus technicusokkal „a bennszülöttek gondolatainak a lehető legpontosabb verbális körvonalait" kell megrajzolni. Ennek az eljárásnak pedig a legfontosabb feltétele a bennszülött nyelv elsajátítása, mely - mint fentebb szó volt róla - minden szabály, törzsi hagyomány kódolásának Malinowski szerint elsődleges szimbolikus eszköze. 28.

2.4. Amint az ebből a roppant elnagyolt összefoglalóból is valószínúleg látható, Malinowski az elmélet és kutatásmódszertan összefüggő, koherens rendszerét igyekezett megalkotni. Ez a rendszer azonban ebben a formában, hosszú távon nem bizonyult fenntarthatónak, s nem csupán azért, mert - mint személyes naplója mutatja - ő maga sem tudott maradéktalanul megfelelni annak. Az egyik probléma a Malinowski módszertanából következő azon alapfeltevés volt, hogy a kutató képes a bennszülött szemszögéből látni a kutatott társadalmat. Ez a native point of view, vagy másképp „émikus” - a kultúrát belülről, a saját fogalmain keresztül megragadni szándékozó, a tanulmányozott közösség látásmódját, annak logikáját átvéve megvilágító - szemlélet, a Malinowski módszereit követő etnográfiában egyre fontosabb lett, s a „bennszülötté válás” törekvésében fogalmazódott mintegy programmá. Ez a program pedig egyrészt azt sugallta, hogy az etnográfus képes - a sokszor attribútumává is váló - fényképezőgépnek tulajdonított objektivitással vizsgálni az idegen kultúrát, másfelől pedig azt, hogy ezzel párhuzamosan az etnográfus személyisége (s vele együtt az „otthoni” kultúra sajátos látásmódja, értékrendje, az etnográfussal szemben támasztott elvárások, stb.) nincsen jelen a kutatás folyamatában és eredményeiben. A napló azonban „elkerülhetetlenné tette annak elismerését, hogy az antropológiai tudáselőállítás mélyen szubjektív momentumokban gyökeredzik, amelyek nem tarthatók a tudomány határain kívül. Ez pedig alaposan megrengette az antropológia tradicionális önképét, s új episztemológiai, politikai s etikai kérdések sorához vezetett. Az ennek nyomán bekövetkező fordulat bizonyos értelemben akár a 40 évvel korábbi inverziójának is tekinthető: a figyelem a terepmunkáról a másodlagosnak tekintett $\mathrm{s}$ az elméletalkotásban mellőzött írás folyamatára, az antropológia diszkurzivitására és textualitására került át. A terepkutatók (újra) felfedezték filológus (szerző) mivoltukat” (N. Kovács 1999:482).

29.

A fordulat mögött természetesen sok egyéb fontos hatás is kimutatható. Ezek közül az egyik a gyarmati múltjával szembenéző antropológia zavara. Az 1960-as évek társadalmi változásai nyomán a kulturális antropológiának mint diszciplínának is szembe kellett nézni a gyarmatosításban játszott szerepével, s ez a folyamat számos olyan kérdéshez vezetett, mely az antropológia tudományos környezetén túl a hatalmi környezet és az etnográfiai terepmunkák során megtermelt tudás összefüggésére világítottak rá, megkérdőjelezve utóbbiak megbízhatóságát. Ezt a 
helyzetet bonyolította az addig többnyire csak kutatottként számon tartott kultúrák köréből érkező antropológus szakemberek megjelenése, és kritikája az ő kultúrájukkal foglalkozó nyugati interpretációkkal kapcsolatosan. 30 .

A másik fontos körülmény az egyre határozottabban kibontakozó globalizáció, melynek egyik fontos következménye az antropológusok által addig nagy előszeretettel vizsgált - Malinowski által is említett - távoli, kisléptékű kultúrák eróziója volt. A különböző természetủ javak és az emberek egyre növekvő mobilitásával párhuzamosan egyre kevésbé volt tartható az egy adott területhez kötődő, zárt és e keretek közt összefüggő kultúráról kialakított elképzelés. Ahogyan ennek feladására kényszerültek, az antropológusok egyre határozottabban arra a felismerésre jutottak, hogy ezek a korábban zártnak feltételezett kultúrák talán nem is voltak annyira s olyan formában zártak, ahogy feltételezték [15], vagyis „a terepkutató által kiválasztott és jól áttekinthetô terepből adódik a kifelé zárt és befelé homogén kultúra konstrukciója.” (N. Kovács 1999: 483) Ennek a folyamatnak köszönhetően egyrészt megnőtt az antropológia reflexivitása, és egyre fontosabbá váltak az etnográfiai tudás létrejöttére és természetére vonatkozó kérdések. Ezzel párhuzamosan a konkrét kutatások hangsúlya is eltolódott az objektívnek gondolt tények számbavételéről a megfigyelések értelmezése felé, a megfigyelt viselkedések helyett a viselkedéseknek jelentést adó, illetve tulajdonító társadalmi diskurzusok fel. Ezt a folyamatot az antropológia ,interpretív fordulatának” nevezik, egyik kulcsfigurája pedig Clifford Geertz amerikai antropológus volt.

Az interpretív antropológia alapállása, s így Geertz számára is a kultúra alapvetően szövegtermészetü, ami azt jelenti, hogy értelmezése, a jelentés keresése és létrejöttének vizsgálata egy sajátos hermeneutikai folyamat, s nem ez az egyetlen antropológián kívüli tudásterület, melynek eredményeit és gondolatait Geertz saját antropológiájának felépítése során felhasználta. Az általa a ,jelentések nyomába szegődő" tudományként elgondolt antropológia erősen támaszkodik Heidegger és Gadamer hermeneutikájára, mely a hermeneutikai, jelentéskereső és tulajdonító tevékenységet a szövegekkel való foglalatoskodásról az emberi élet egészét átfogó attitúddé terjeszti ki, s ezzel párhuzamosan a jelentés lehetőségét is kiterjeszti a szövegekról minden emberi alkotásra (N. Kovács 1999:484). Ez a hermeneutikai problémafelvetés egyértelmüen megjelenik Geertznél, amikor az etnográfia művelését ahhoz a tevékenységhez hasonlítja, ,amikor megpróbálunk elolvasni egy kéziratot (abban az értelemben, hogy » létrehozzuk valamilyen olvasatát «) - egy idegen, elhomályosuló, talányokkal, önellentmondásokkal, gyanús javításokkal és célzatos kommentárokkal teli kéziratot, ami azonban nem a hagyományos írásjelekkel, hanem a megformált viselkedés illékony példáival íródott" (Geertz 2001b:202) [16]. Geertz itt már Paul Ricoeur elméletére épít, aki azért tekinti szövegnek az emberi cselekvéseket, mert az íráshoz hasonlóan ezek is nyomokat hagynak maguk után, csak ezeket a társadalmi időben megmaradó társadalmi struktúrák és cselekvésminták teszik láthatóvá. Ricoeur szerint a társadalmi jelenségek szemiotikai értelemben a nyelvi jelekkel párhuzamba állíthatók, és „a társadalmi jelenségek és a szöveg modellje közötti kapcsolatot a szemiológiai rendszer fogalma teremti meg. A szemiológia álláspontja szerint egy nyelvi rendszer csak a szemiotikai minőség egyik alesete - még akkor is, ha ez a minőség más fajtája számára paradigmának számít. Abból indulhatunk tehát ki, hogy ha a magyarázat strukturális modellje általánosítható, akkor minden társadalmi jelenség leírható szemiológiai jellegứnek. Mégpedig úgy, hogy definiáljuk őket egy szemiológiai rendszer különböző szintjein lévő tipikus viszonyként: a kód és a közlemény 
közötti általános viszonyként, a kód speciális alegységei közötti viszonyokként, a jeladó és a jelzett közötti kapcsolatokként, a társadalmi közlemények, a kommunikációnak mint a közlemények cseréjének struktúrája közötti és ezeken belüli tipikus viszonyként, stb. Amennyiben a szemiológiai modell használható, akkor felmutatja a szemiotikai vagy szimbolikus funkciót, azaz a jelek helyettesítésének funkcióját, amely mindig több a társadalmi élet másodlagos hatásánál. Éppen ez a funkció a társadalmi élet tulajdonképpeni alapja. A szemiotika ezen általános funkciójának megfelelően, abból kell kiindulnunk, hogy nem egyszerúen csak a szimbolikus funkció társadalmi, hanem maga a társadalmi valóság szimbolikus alapzatú" (Ricoeur 2001).

32.

Ennek a társadalmi valóságnak azonban nem a felszíne, a cselekvések és viselkedések maguk, hanem a „mély-szemantikája” az, ami Ricoeur szerint érdekes. Ez pedig „nem olyasmi, amit a szerző maga ki akart volna fejezni, hanem olyan valami, amiről a szöveg, pontosabban a szöveg nem nyilvánvaló viszonyai szólnak. És a szöveg nem nyilvánvaló viszonya az a világ, amelyet a szöveg mély-szemantikája képes magába zárni. Amit tehát meg akarunk érteni, az nem olyan valami, ami a szöveg mögött van, hanem az a valami, ami nyíltan előttünk fekszik. Nem az eredeti diskurzus-helyzetet kell megértenünk, hanem a lehetséges világra való utalásokat. A megértésnek csak kevéssé kell foglalkozni a szerzővel és helyzetével, inkább a szöveg révén megnyíló világok jelentéseit érdemes megragadni. Egy szöveg megértése azt jelenti, hogy követjük az értelemtől a vonatkozásig tartó mozgást, abból kiindulva, amit mond, elmenve addig, amiről szól" (Ricoeur 2001). Amit viszont megértünk ebből, ,amit a magunkévá teszünk - amit elsajátítunk -, nem valamilyen idegen tapasztalat, hanem saját fáradozásunk eredménye, egy olyan világ öntudatba emelése, amelyre a szöveg viszonyai utalnak” (Ricoeur 2001). 33.

Ezután talán többnek tûnik Geertz minden bizonnyal leghíresebb kultúra-megfogalmazása, mint egy mókás bonmot. Geertz a sürü leírásról szóló tanulmányában írja, hogy az a kultúrafogalom, amely mellett érvel, lényegét tekintve szemiotikai jellegú. „Max Weberrel [17] együtt úgy vélem - írja - hogy az ember a jelentések maga szőtte hálójában függő állat. A kultúrát tekintem ennek a hálónak, elemzését pedig éppen emiatt nem törvénykereső kísérleti tudománynak, hanem a jelentés nyomába szegődő értelmező tudománynak tartom. A kifejtést tartom célomnak, a felszínen rejtélyes társadalmi kifejezések magyarázatát" (Geertz 2001b:196). Azzal, hogy az etnográfus dolgát az értelmezésben és nem a törvények keresésében határozza meg, Geertz az etnográfiát Tylorral és Malinowskival szemben sokkal inkább a humán, mint a természettudományok felé közelíti. Ez azonban egy „pengeél”, aminek a veszélyeit ô maga is látja, amikor ugyanígy igyekszik eltávolítani az etnográfiát a szimbólumok végletesen intuitív értelmezésétől, ami egyfajta kabalisztikához vezetne [18].

Ennek a kifejtő-magyarázó módszernek a megnevezésére használja Geertz a Gilbert Ryle-tól kölcsönzött sűrủ leírás fogalmát. Geertz hosszasan idézi Ryle egyik példáját, melyben egy kacsintás lehetséges értelmezéseit vázolja fel. Ryle a kacsintás köré számos fiktív helyzetet teremt, s azt mutatja meg, hogy az, aki csak a kacsintást látja, nem tudja értelmezni, hogy pontosan mi is történik, hiszen az nem biztos, hogy kacsintás, lehet hogy csak egy akaratlan szemrándulás, egy „tikk”, vagy a kacsintás próbálgatása vagy a tikk utánzása, stb. Ryle a szemhéj összehúzásának aktusát tartalmazó leírást nevezi ritka, míg a helyzetet és kontextusokat is bevonót sürü leírásnak. Amikor Geertz az etnográfiai tevékenység fókuszában álló 
„kézirat” olvasását nehezítő homályosságról, gyanús javításokról és célzatos kommentárokról ír, akkor Ryle gondolatait továbbfüzve arra hívja fel a figyelmet, hogy az etnográfus nem is találkozik „tiszta” cselekvésekkel, nem látja magát a „kacsintást”, mert minden, amit megfigyel, amivel foglalkozik, már értelmezett: vagy maga a cselekvő vagy a környezete, stb. értelmezi, s az etnográfusnak ezekkel az értelmezésekkel van leginkább dolga.

35.

Geertz számára a sürü leírás az etnográfia lényege, annak megértése pedig, hogy mit jelent etnográfiát múvelni, az antropológiai elemzés, mint tudásforma megértésének kulcsa (Geertz 2001b:196). Ez számára azonban alapvetően nem módszertani kérdés, és talán innen érthetô meg leginkább, hogy Geerz konkrét terepmunka módszereiben - melyek rendre megjelennek a tanulmányaiban, hiszen a sűrű leírásnak része a jelentésekhez való hozzáférés folyamatának nyilvánossá tétele is - nem tér el radikálisan a Malinowski-féle eszköztártól. A munka „kimenete" azonban egészen más. Egyrészt, mint Geertz is megjegyzi, a kultúra értelmező elemzése a modern tudományra jellemző monografikus-szisztematikus építkezéssel szemben lökésszerű, „egyre merészebb kirohanások elszigetelt pontjaiból álló, ám következetes sorozatában tör előre" (Geertz 2001b:219). A kutatások itt is egymásra épülnek, egyik a másik eredményeit használja fel, de minden kulturális elemzés a kezdetektőll indul el, tapogatózva a korábbi vagy máshonnan vett felkészültségeket az adott probléma összefüggésében fokozatosan vonja be az interpretációba. Egy elemzés pedig akkor jó, ha ezzel a lendülettel mélyebbre jut, mint egy másik. Ebből következik a kulturális elemzés másik sajátossága: elsődleges formáját nem a monográfiák vagy átfogó tanulmányok, hanem az esszészerü szövegek jelentik. A kulturális elemzés célja nem $X$ vagy $Z$ kultúra átfogó leírása, vagy hogy „a legmélyebb kérdéseinkre választ adjon, hanem az, hogy hozzáférhetővé tegye számunkra azokat a válaszokat, amelyeket más emberek [...] adtak ezekre a kérdésekre..." (Geertz 2001b:226). 36.

Ennek módjával kapcsolatosan Geertz egyik legfontosabb megállapítása az, hogy a kulturális elemzés „mikroszkopikus”. Itt azonban nem annyira arról van szó, hogy az antropológusok kisléptékủ, jól be- és átlátható társadalmakban (s pláne nem arról, hogy efféle társadalmakat) kutatnak. A sűrú leírás az etnográfus által megfigyelt és reflektált, tudatossá tett - akár a Malinowski naplójában is szereplő aprócseprő, jelentéktelennek, sőt olykor idegesítőnek tünő - jelenségeket értelmezi különböző kommunikációs szituációkban és a Ricoeur által említett szemiológiai viszonyokban, illetve helyezi különböző szintủ általánosabb értelmezési keretekbe. Ezek az apró-cseprő ügyek ugyanis a lenyomatai, „,́rásjele” a kultúrának, mint szövegnek. Ezekben mint megtestesült szimbólumokban érhetőek tetten leginkább kézzelfogható módon azok a koncepciók, amelyek segítségével az emberek kommunikálnak egymással, állandósítják és fejlesztik az élettel kapcsolatos tudásukat és attitúdjüket [19]. Ezen jelenségek értelmezése során a legáltalánosabb struktúra és a legspecifikusabb részlet közti állandó ingázás, mint az elemzés eszköze pedig nem csupán az - igen sokszor történetmesélésbe ágyazott jelenség - elbeszélést de a megértést is fokozatosan előbbre viszi. 37.

Jellegzetes példája ennek az interpretációs eljárásnak Geertz bali kakasviadalról írt szövege, ahol az eseménystruktúráját egy saját élmény elbeszélésébe ágyazva bontja ki, s a történetelbeszélés előrehaladása során mire a végkifejlethez érünk, a perspektívaváltások sorozatán keresztül a viadal kulturális jelentőségének értelme is feltárul (lásd Geertz 2001c). Miközben Geertz leírja az egyedi, partikuláris és 
személyes élményt, a jelentése megtalálásának lehetőségét megadó struktúrák közötti váltakozásokkal egyszersmind (szándéka szerint) ki is szabadítja azt egyediségéből, partikularitásából és személyességéból, s arra a világra - a bali kultúrára - mutat rá, amit a társadalmi jelenség mély-szemantikája magába zárt. Ugyanakkor mindez mégis elválaszthatatlan a megértő személyétől, $\mathrm{s}$ ezt is remekül jelzi a szöveg. A bali kakasviadal ugyanis nem csupán egy balinéz kulturális jelenség kontextuális értelmezése, hanem ebbe ágyazva az antropológusnak a helyi társadalomba történő belépését, a megértést lehetővé tevő, a kutató és a kutatottak közti jelentésközösség kialakulását elbeszélő paradigmatikus történet is egyben.

\section{Változó antropológia}

A tanulmányom eddigi részében bemutatott kutatók semmilyen módon nem reprezentálják a kulturális antropológia történetét, nem illeszkednek szigorú logikai sorba - jóllehet kapcsolatuk több esetben nyilvánvaló - és természetesen nem ölelik fel sem a kultúra értelmezésének, sem pedig a terepmunka módszertanának teljességét. Rövid és meglehetősen elnagyolt bemutatásukkal egyetlen célom az volt, hogy az általuk használt kultúrafogalom és az általuk müvelt etnográfiai terepmunka sajátos kapcsolatára rámutassak. A felsorolás egyik fontos hibája az, hogy bár van egy kvázi történeti szál benne, az mégsem vezet sehová. Ez azonban némileg szándékos. Hiba lenne ugyanis az antropológia bármilyen értelemben vett történetét, mint egyfajta „,fejlődéstörténetet” bemutatni. Legfeljebb az elméletek és gyakorlatok változásáról beszélhetünk, mely változások - tekintettel arra, hogy a kulturális antropológia alapvetően ezen civilizáció önértelmezésének egyik fontos eszköze volt, és talán az lehet ma is - többnyire a (késő, stb.-)modern nyugati társadalom változásaira reflektálnak. Ezek a változások természetesen napjainkban is folyamatosak, így az antropológia kultúrafelfogása és terepmunka módszertana is változóban van. Ezeket, minthogy magunk is részesei, alakítói és elszenvedői vagyunk viszonylag nehéz átlátni, ráadásul - személyes tapasztalatom szerint - az a sajátos helyzet állt elő, hogy a terepmunka módszertana sokkal gyorsabb tempóban változik, mint a használatos kultúrafogalmak [20], mindazáltal a következőkben három olyan területen kísérlem meg bemutatni a változásokat, melyek az eddigiekben is fontosnak bizonyultak.

39.

3.1. Az első terület a „terep” mibenléte, az ezzel kapcsolatos változások. Arra a kérdésre, hogy mi a terep és hol található, az etnográfusok hosszú ideig alapvetően egy territoriális meghatározottságú választ adtak. Tylor a modernitás számára definitív másikkal való találkozás helyeként tekint a terepre, Malinowski pedig ki is emeli, hogy az etnográfiai kutatás számára kulcsfontosságú a kutató térben való eltávolodása a saját kultúrájától, illetve az így létrejövő magány és elszigeteltség. Geertz ezt már nem tartja fontosnak, jóllehet ő maga is ilyennek tekinthető terepeken kutatott [21], de az ilyen, a nyugati civilizációtól szükségszerűen távol eső kutatási helyszínek választását nem tekinti kritériumnak. Részben azért sem, mert nem is tekintheti annak. 40.

Ahogy korábban utaltam rá, a globalizáció folyamatainak következtében ezeknek a helyeknek a határa, „zártsága” egyre érezhetőbben oldódik fel, s így egyre ritkábban találni olyan helyeket, melyek megfelelnek az antropológia tereppel szemben támasztott klasszikus elvárásainak. Innen is érthető az antropológia interpretív 
fordulatával párhuzamosan, az annak hátterében álló válságok és változások másik következményeként lejátszódó, az „antropológia hazatérésének” nevezett folyamat, vagyis az, hogy az antropológusok egyre gyakrabban kezdenek kutatni a saját, vagyis a nyugati civilizáció körébe tartozó társadalmukban, s egy idő után elkezdik vizsgálni ezt a társadalmat magát. A globális migrációs folyamatok következtében ugyanis egyrészt rájönnek, hogy szinte egy lépést sem kell tenniük ahhoz, hogy az „idegennel” találkozzanak, hogy megismerjenek olyan „más” kulturális csoportokat, melyek a Geertz által felállított szempontnak eleget téve más, a sajátjuktól eltérő válaszokat adnak az emberlét kérdéseire. Másrészt arra is rájönnek, hogy a saját kultúrájuk is meglehetősen tagolt, s bár egy idő után éppen ez lesz az antropológia egyik fő kérdése, de feltételezik, hogy a nem nyugati kultúrák vizsgálatára a modernitás szellemi környezetében kialakított fogalmi apparátus alkalmas lesz vagy lehet a nyugati, posztmodern társadalmak kutatására is [22]. (Ezeket a folyamatokat átfogóan mutatja be Niedermüller 2005.)

Ezzel párhuzamosan megváltozik a hely, vagyis a társadalmiasított tér fogalma is a társadalomtudományokban, s így az antropológiában is. Míg korábban a helyek meghatározó módon topográfiai hivatkozások voltak, addig e változás során sokkal inkább a vizsgált társadalmi jelenségek színtereire kezdenek utalni. A kultúra territoriális felfogásának ilyen jellegű megkérdőjelezése az európai etnológiában, illetve néprajztudományban már az 1960-as évektől kezdve jelen volt. Az eredetileg folkloristaként számontartott Hermann Bausinger 1961-ben megjelent Volkskultur in der technischen Welt címü, vitairatnak szánt müvében fejti ki a „hely egységéről” kialakított, a „falura jellemző stílusjegy”, vagyis a közösséget öszszefogó kulturális minták meghatározásával kapcsolatos, fenomenológiai megalapozottságú - és a színpadi dramaturgiától kölcsönzött - koncepcióját. „Miközben az „egységes falu” kifejezés - írja Bausinger - öntudatlanul is az egyetértés asszociációját kelti, s így közel áll a minden részében összehangolt, zárt organizmus elképzeléséhez, a „hely egysége” megjelölés csupán a történet terét jelöli ki. Ez a történet nagyon különböző karaktereket, nagyon különböző cselekvéseket, a cselekvések nagyon különböző motivációit fogja át; beleértve a konfliktusokat és feszültségeket is: csak így keletkezik a színpadon valódi dráma. Ám az összetartozó, egymásra vonatkoztatott történet és a hely egysége csak az egyik dramaturgiai út, melyen keresztül létrehozhatjuk az összetartozás tiszta horizontjait. Így - szándékaink szerint - valamely hely egysége a valóságban nem egy, a helyet egységesen átható etikai elv mentén jön létre, hanem olyan horizontokon keresztül, amelyek a történés együvé tartozását és az értelmezési lehetőségeket lehatárolják. Ami ezen a horizonton túl van, egyáltalán nem kerül be a látótérbe" (Bausinger 1995:55). Bausinger a későbbiekben részletesen elemzi azt, hogy elsősorban a kommunikáció különböző technikái - beleértve úgy a szellemi, mint az anyagi javak terjedését hogyan erodálták ezeket a határokat, hogyan tették egyre bizonytalanabbá ezeket a horizontokat. Ugyanakkor - elsősorban a nyelvhasználaton keresztül - azt is elemzi, hogy minden erózió ellenére, jóllehet földrajzi határokként ezek általában nem azonosíthatóak, a horizontok léteznek, s különösen akkor válnak kitapinthatóvá, ha valaki kívülről, idegenként lép be az általuk definiált értelmező kontextusba (Bausinger 1995:59). 42.

Nagyon hasonlóan ír a kulturális jelentések termelésének és a jelentés-közösségek horizontjainak definiálását meghatározó kommunikatív aktusoknak a szerepéről Arjun Appadurai a lokalitás teremtéséról szóló elméletében. Az appadurai-i lokalitás-fogalom a kultúra egy sajátos kommunikatív, vagy diszkurzív megközelítését 
teszi lehetővé. Számára „a lokalitás mindenekelőtt kapcsolatokat és kontextusokat, és nem fokozatokat vagy térbeliséget jelent... melyet a társadalmi közvetlenség érzete, az interaktivitás technológiái, és a viszonylagossá vált kontextusok közötti kapcsolatsor hoz létre (Appadurai 2001:3). Az interaktivitás technikái segítségével aktualizálják, érvényesítik és adják tovább a lokális szubjektumok - a rokonság, a szomszédok, a barátok és az ellenségek meghatározott közösségéhez tartozó, vagyis a lokalitás mint interakció folyamataiban résztvevő szereplők - a hagyományt, s ezekben a folyamatokban reprodukálják magát a lokalitást. Ebben a folyamatban kiemelkedő szerepet töltenek be az identitás szimbólumai, azon helyek és tárgyak, melyeket a lokalitás már „magáévá tett”, amelyekben végső soron „elnyeri anyagi mivoltát” (Appadurai 2001:5), s amelyeket más elméleti keretek között az emlékezet helyeinek nevezünk. Appadurai felveti azt is, hogy azok a társadalmi jelenségek, melyeket az antropológusok tanulmányoznak, kivált a(z átmeneti) rítusok értelmezhetők a lokalitás felmutatásának és újrateremtésének aktusaként is.

Appadurai a lokalitás mellé helyezi a szomszédság fogalmát, amivel azokra a ténylegesen létező társadalmi formákra utal, „amelyekben a lokalitás mint dimenzió vagy érték, változatos módon nyilvánul meg. A szomszédságok ebben az értelemben olyan megragadható közösségek, amelyeket realitásuk - legyen az térbeli vagy virtuális - és a társadalmi reprodukcióra való képességük jellemez" (Appadurai 2001:3-4). A szomszédság és a lokalitás közötti kapcsot a helyi tudás jelenti, ami annak ismerete, hogy „miként kell megbízható lokális szubjektumokat, valamint olyan lokális szomszédságokat létrehozni, amelyekben ezek a szubjektumok felismerhetők és szervezhetők lesznek. Ebben az értelemben helyi tudásnak nem azt tekintjük, ami alapvetően ellentétben áll egyéb tudásokkal - és (nem lokális nézőpontból) a megfigyelő kevésbé lokalizáltnak tart -, hanem amit a helyi teleológia és éthosz annak tekint” (Appadurai 2001:6). A helyi tudás vagy a történések, jelenségek értelmezési lehetőségét lehatároló, a együvé tartozását definiáló horizontok pedig a jelentéseknek éppen azt a hálóját jelölik, melyekről Geertz a kultúra meghatározásakor ír.

44.

Jóllehet a bemutatás itt is elnagyolt, mindenesetre azt jelzi, hogy a helyek territoriális felfogásától elszakadva, s azokat gyakorlatilag metaforaként fogva fel, eljutunk a terep egy sajátos kommunikatív értelmezéséhez, melyben az egy összetett módon jellemezhető kommunikációs színtér, a részesedés helye lesz. Ezen a színtéren két problémamegoldási folyamat játszódik le párhuzamosan. Az egyik a kutatóé, aki meg szeretné érteni az adott kultúra múködését, azt, hogy a társadalmi létezés egy-egy problémáját a helybéliek hogyan oldják meg, milyen válaszokat adnak rá. A másik a „bennszülötteké” (mondjuk egyenlőre így) akiknek megvan a maguk problémája, ami többnyire a kultúrájuk, társadalmuk múködtetése. A terepmunka klasszikus felfogása szerint a kettő egymásba kapcsolódik, vagyis a kutató úgy oldja meg a maga problémáját, hogy belép a bennszülött kommunikáció színtereire, résztvevőmegfigyelő ágensként gyakorlatilag a színtér részesévé, „bennszülötté” próbál válni. A Geertz-fele felfogás ezzel szemben mindvégig hangsúlyozza a két színtér különállóságát. Geertz soha nem akart bennszülötté válni, az ő célja a beszélgetés a bennszülöttekkel, a szóba elegyedés, így kutatói részvétele a bennszülött problémamegoldás színterein a spektátor, a megfigyelő szerepére korlátozódik. Ez a szerep viszont, és az, hogy mindvégig határozottan a saját problémamegoldásának színterén mozog, lehetőséget ad arra, hogy a bennszülött kul- 
túra különböző színtereire „rálásson”, azokat mint egymásba érő értelemteli struktúrákat egymásra vonatkoztassa. Amikor azonban a terepet a részesedés helyeként határozzuk meg, akkor mindkét korábbi koncepcióval lényegében szakítunk. Jóllehet nem akarunk bennszülötté válni, ennek a vállalkozásnak a lehetetlensége eléggé nyilvánvaló, ugyanakkor az is nyilvánvaló, hogy az antropológus nem tudja megôrizni a kívülálló spektátor minőségét sem a terepen. Nem tud úgy jelen lenni, hogy ne avatkozna be a folyamatokba, sőt jelenléte - még akkor is, ha történetesen nem fizet egy-egy szertartás megtartásáért a bennszülötteknek - „beleértődik” a történésekbe. Amikor tehát úgy határozzuk meg a terepet, mint a részesedés helyét, akkor részesedés alatt azt értjük, hogy a kutató célja az, hogy részesedjen azokban a felkészültségekben, melyekkel felismerheti a bennszülöttek problémáját, mint problémát és részt is vehet azok megoldásában. Ez nem azt jelenti, hogy a kutató bennszülötté válna, hanem azt, hogy a bennszülöttek szemszögéből ő lesz az, az idegenség és a „közülünk valóság” közti széles mezsgyén többnyire változó helyzetben lévő valaki, aki együtt dolgozik velünk bizonyos problémák megoldásán, akit megtanítunk arra, hogy hogyan folyik az élet mifelénk. 45.

Ez a részesedés azonban kölcsönös. Arról viszonylag hosszabb ideje írnak az antropológusok, hogy az általuk okozott „kellemetlenségekért” cserébe bizonyos javakat vagy szolgáltatásokat nyújtaniuk kell a bennszülötteknek. Ez éppúgy lehet néhány üveggyöngy, mint az, hogy az antropológus megír egy kérelmet a gyarmati tisztviselőhöz a bennszülött nevében. Az az antropológiai gondolkodás azonban, mely a részesedést állítja az etnográfiai terepmunka fókuszába, ennél jóval komplexebben, egy sajátos együttmúködésként, kollaborációként tekint a bennszülöttekkel való munkára, s ez összefügg azzal, hogy - mint arról alább részletesebben is szó esik - megváltozik a másik, az idegen, a bennszülött státusza is az antropológiai kutatásban. 46.

Ha a terep a részesedés helye, akkor a terep helye ott van, ahol a kultúra „történik", ahol a problémamegoldási folyamatban résztvevő ágensek vannak, ahol ezek az ágensek közösen és kölcsönösen elérhetővé teszik a problémafolyamat aktuális pontján relevánsnak ítélt tudásaikat, attitűdjeiket, stb., egyszóval: felkészültségeiket. E felkészültségek segítségével az ágensek között „feszül ki” mintegy porond vagy pást a terep, mint kommunikációs színtér. Ez a kifeszülés magába foglalhat nagyon távoli de nagyon közeli területeket is, de különböző mediális természetű közegeken is átívelhet. Így lesz része, terepe az antropológiai kutatásnak a cybertér. A közegek természete és az ebból adódó módszertani problémák - menynyire máshogyan kutatunk egy mexikói faluban, mint egy online játék rajongói közösségében az interneten - természetesen nem lényegtelenek, de a súlypont nem ezeken van, hanem azon, hogy a terepet nem a kutatás helyszínének topográfiai kiterjedése definiálja, hanem a társadalom és a probléma, amivel a kutató foglalkozik.

47.

Ennek a részletes kifejtését tartalmazza Georg E. Marcus (1995) multi-sited ethnography koncepciója. Az kiinduló szövegnek tekintett 1995-ös tanulmányában Marcus alapproblémáját az a kérdés jelenti, hogy miképpen tud lépést tartani az etnográfia a „kis léptékú társadalmi keretekbőll” kilépő tárgyával, illetve hogyan tud módszertanilag alkalmazkodni azokhoz az egyre szélesedő - és egyre inkább elmosódó - globális horizontokhoz, melyek felé vizsgálatának tárgyai elindulnak. Vagyis: hogyan marad alkalmas az etnográfia sajátos tárgyainak vizsgálatára úgy, 
hogy tárgyát egyre inkább olyan - globalizációs - kontextusokban, kapcsolathálózatokban kell elhelyeznie, illetve definiálnia, melyek belátására módszertanilag kvázi vak? Marcus azt írja, hogy a válasz az, hogy az etnográfus menjen a tárgya után, s a tárgy körül fogja írni a kutatás terepét. A körülírás mikéntjét szövegében személyek, tárgyak, metaforák, tervek, történetek, allegóriák, életutak, biográfiák és konfliktusok követésének összefüggésben mutatja be. Marcus gondolatmenetében nem annyira a „követés” kifejezés esetleges metaforikus használata az érdekes, hanem az, hogy maga a terep (field) fogalma válik metaforává. Megközelítésében a terep nem egy topográfiai értelemben kijelölhető hely, hanem egy olyan koncepció, olyan „gondolati tér” - s mint ilyen, a kutató értelmező tevékenysége során létrejött konstruktum, ami egyben a kutatást meghatározó "tudás", azaz felkészültség a kutató számára - mely összeköti azokat a site-okat, vagyis nagyon különböző kommunikációs színtereket, melyeken a kutató a kutatás logikáját meghatározó problémát követi; illetve amely éppen ezekből a site-okból jön létre. A terep ilyen elgondolásában az egyes site-ok a kutató számára olyan - önmagukban is rendkívül komplex - felkészültségeket jelentenek, melyek mentén a terep, mit a kutató - a kutatás értelmében vett - problémamegoldó színtere kifeszül. Kommunikációelméleti összefüggésben ugyanis a kommunikáció színtere a résztvevő ágensek felkészültségei mentén jön létre. (Ez tkp. annyira nem új dolog, például a terepmunka során készített feljegyzések, azaz a kutató kihelyezett tudása, felkészültsége mentén feszül ki, jön létre vagy "áll össze" a kutató számára a terep, s ami nincs a jegyzetekben az nincs a terepen sem.) A színtérben a „tér” itt is metafora, bár adott esetben utalhat egy konkrét térre is. A terep ebben a megközelítésben egy roppant összetett, rétegzett és sajátos történetiséggel rendelkező színtér, mely magába foglalja az egyes - önmagukban is problémakezelő színtérként értelmezhető - site-okat, s az ezekból például tapasztalatként reflektálva felépített konstrukciót (field) csakúgy, mint azokat a színtereket, melyeken a kutató más problémakezelési folyamatok összefüggésében erre a konstrukcióra (is) hivatkozik. 48.

A terep metaforikus értelmezésével párhuzamosan a terepmunka is elgondolható egy sajátos metaforaként, mégpedig interfész-metaforaként. Az interfész fogalma mára meglehetősen közismert. A számítástechnikából átvett, bár annak területén messze túlmutató érvényességü fogalom a számítógép és annak perifériái (például nyomtató) illetve a gép-ember közti kommunikációs csatoló felületet (utóbbi esetben például képernyő, különösen is az érintôképernyő) jelöli s mindig hangsúlyos része jelentésének a kódolás/dekódolás mozzanata. Az interfész teszi ugyanis lehetôvé a gép részei közötti, és a géppel való kommunikációnak az összehangolását, ezért az interfészhez egyszerre tartozik hozzá maga a kapcsolódási felület és a leírás, amely meghatározza, hogy azon keresztül hogyan csatlakozhatnak egymáshoz az ágensek, hogyan kell az egyik nyelvéről a másikéra fordítani a kommunikációs jeleket. Ebből a technikai megközelítésből kiindulva, de általánosabb jelentéssel mint mindenféle csatoló-kódoló/dekódoló „felület” - kezd az interfész fogalma visszatérni a mindennapi szóhasználatba, s így használható a terep értelmezésében is. Ha ugyanis a terep azon színterek metaforikus konstrukciója, ahol a kutató részesedhet bizonyos felkészültségekben (és megoszthat másokat), akkor a terepmunka a részesedés folyamatára használt interfész-metafora, $s$ mint ilyen, a részesedést magát is szabályozza. Az interfész-metafora fogalma Georg Legrady (a kifejezés megalkotója) szerint egy hipermédiában ,... olyan szervező-modellként funkcionál, amely konceptuálisan elhelyezi a nézőt és keretet vagy logikus adathozzáfé- 
rést biztosít” (Legrady 1996). Olyan építészeti környezetekre vagy kalandos „kincsvadász" történetekre kell például Legrady szerint gondolni, amelyek mindegyike saját referencia-modellje logikája szerint múködik. A „történet” vagy metafora logikájának ismeretében sikeresen közlekedhetünk az adathalmazban, és megszerezhetjük a számunkra fontos információt. „Ezek a metafora-környezetek a néző digitális környezetben szerzett interaktív tapasztalatait, élményeit újradefiniáló innovatív nyelvészeti, szimbolikus, esztétikai, érzéki és konceptuális fejlődés legfontosabb színtereinek ígérkeznek. (...) Az interfész metafora az a kontextus, amely összefüzi a történeteket és megadja a mú értelmét” (Legrady 1996). Az interfész-metafora lényege tehát az, hogy az interfész múködését egyszerüsíti le, a használt metafora - egy láthatóként megjelenített kép vagy egyszerüen egy fogalom kiemelése - segítségével helyezi el a felhasználót, illetve értelmezi a felhasználó és a tartalom közötti kapcsolatot.

3.2. A második fontos terület, amelyen jelentős változások mentek s mennek végbe az antropológiai gondolkodásban az a „másikról”, az „idegenről” vagyis a terepen az antropológussal együtt jelen lévő ágensekről való gondolkodás. A terep fogalmával párhuzamosan ugyanis folyamatosan változik a „bennszülöttek” státusza is. Ez azonban egy nagyon összetett folyamat, melynek két oldala van. A Peruban kutató dán etnográfus, Karsten Paerregaard egy tanulmányában új megvilágításba helyezve szinte heurisztikus értéket ad annak az etnográfiai közhelynek, miszerint a kutató és a kutatottak kapcsolata meghatározza az etnográfiai kutatás eredményességét (Paerregaard 2002). E kapcsolat leírására, értékelésére hosszú ideig nem nagyon fordított figyelmet a tudomány. Esetleg egy-egy lábjegyzetben megjegyezte az etnográfus, hogy ezzel és ezzel az adatközlővel jó vagy konfliktusos volt a viszonya, vagy a bennszülöttek ekkor és ekkor ellenségesen vagy támogatólag viszonyultak a kutatáshoz, de az eredmény értékelése szempontjából ritkán váltak lényegessé ezek a megjegyzések. Van persze néhány kivételes eset, például Margaret Mead Derek Freeman által felderített „megvezetése” Szamoán (Freeman 1998), vagy Nigel Barley, a „zöldfülü antropológus” rácsodálkozása a bennszülöttekről kialakított előzetes képe és a velük kialakított konkrét viszonyok konfliktusára és ennek a kutatás eredményességére gyakorolt hatására (Barley 2006). Szerzőnk szerint viszont az, ahogyan a vizsgált társadalom tagjai saját kategóriarendszerükben elhelyezik a kutatót - vagyis ahogyan elnevezik, amilyen szerepeket aggatnak rá, stb. - meghatározza azon tudások / tapasztalatok / élmények - illetve ezek kultúrán belüli reprezentációinak és interpretációinak - körét, melyek a kutató számára elérhetővé válnak vagy válhatnak. Paerregaard (2002), csakúgy mint Geertz az etnográfiai tudástermelés „dialogikus” - vagy interaktív - felfogását vallja, vagyis úgy véli, hogy a kutató nem férhet hozzá közvetlenül az általa tanulmányozott kultúrához, hanem az adatközlőivel folytatott dialógusban állítja elő azt a realitást, amelyet „kutat” - ahogyan az egyébként sem létezik önmagában, az efféle diskurzusoktól függetlenül. Paerregaard ezt annyiban módosítja, hogy nem annyira vagy nem csupán diskurzusokról, hanem a kutató és a kutatottak egymással megosztott élményeiről, tapasztalatairól beszél, s e „megosztásnak”, a kutatóra alkalmazott megnevezések, illetve hivatkozások alapján, három szintjét különbözteti meg: 50.

1) A kutató a másfajta (the other) vagyis az idegen, a kívülálló, aki a veszélyességközömbösség (esetleg a nem létezés) kategóriái közötti, meglehetősen tágas térben létezik; 
51.

2) A kutató a köztünk élő de etnikailag/vallásilag/szociálisan más (another one of us). A kutató itt az előző kategóriához képest előre lép, és a Paerregaard terepén használt kifejezéssel élve a gringo-ból misti-vé válik, vagyis amikor az 1. kategóriában a másfajtára használt a nyelvben is idegen kifejezés helyett a 2. kategória leírására használt saját kifejezést alkalmazzák.

3) Egy közülünk (one of us) - az a bizonyos áttörés, aminek Clifford Geertz a bali kakasviadalon a rendőrség elől a bennszülöttekkel való együtt menekülés után részese lett, amelynek következtében olyan kommunikációs módok és a kultúra olyan területei váltak számára elérhetővé, melyek addig nem voltak azok (Geertz 2001c:147-148).

53.

A Szerző nagyon részletesen mutatja be, hogy mindhárom megnevezés - hasonlóan például a beavatásokhoz - meghatározott státusokat, vagyis a megosztható tapasztalatok és tudások meghatározott körét jelöli.

Fordítsuk most meg a Paerregaard (2002) által elemzett szituációt, s tegyük fel a kérdést: vajon az, ahogyan az etnográfusok a terepen velük kapcsolatba kerülő, s számukra információkat közlő emberekre hivatkoznak [23], mit árul el a közöttük lévő viszonyról, s az etnográfiai tudás termeléséről? Tekintsük át röviden a problémát egy táblázat segítségével [24]:

\begin{tabular}{|c|c|c|c|c|c|c|c|c|}
\hline \multicolumn{2}{|c|}{ A Másik hivatkozása } & \multirow{2}{*}{$\begin{array}{c}\text { A } \\
\text { hivatkozásban } \\
\text { megnyilvánuló } \\
\text { viszonyok ill. } \\
\text { attitüdök }\end{array}$} & \multirow{2}{*}{$\begin{array}{c}\text { Átfedések a } \\
\text { szóhasználatban } \\
\text { (a kronologikus } \\
\text { esetekben) }\end{array}$} & \multirow{2}{*}{\multicolumn{3}{|c|}{ Elméleti pozíciók }} & \multirow[t]{2}{*}{ Módszerek... } & \multirow{2}{*}{$\begin{array}{c}\text { k..és } \\
\text { képviselőik } \\
\text { pl. }\end{array}$} \\
\hline állandó & kronologikus & & & & & & & \\
\hline \multirow{8}{*}{$\begin{array}{l}\text { A másikra } \\
\text { történő } \\
\text { hivatkozás } \\
\text { a nép, } \\
\text { törzs, } \\
\text { klán, } \\
\text { család, } \\
\text { stb. } \\
\text { nevével }\end{array}$} & $\begin{array}{l}\text { Vad(ak) } \\
\text { (savage) }\end{array}$ & \multirow{4}{*}{$\begin{array}{l}\text { Hatalmi viszony, } \\
\text { etnocentrista } \\
\text { szemlélet }\end{array}$} & & \multirow{5}{*}{ pozitivista } & & & $\begin{array}{l}\text { „karosszék” } \\
\text { etnográfia }\end{array}$ & Tylor, Frazer \\
\hline & Primitív(ek) & & & & & & \multirow{2}{*}{$\begin{array}{l}\text { klasszikus } \\
\text { terepmunka }\end{array}$} & \multirow[b]{2}{*}{ Malinowski } \\
\hline & $\begin{array}{l}\text { Bennszülött } \\
\text { (indigenous) }\end{array}$ & & & & & & & \\
\hline & $\begin{array}{l}\text { Őslakos } \\
\text { (native) }\end{array}$ & & & & & & "going native" & Benedict \\
\hline & $\begin{array}{l}\text { Adatközlő } \\
\text { (informant) }\end{array}$ & \multirow{4}{*}{$\begin{array}{l}\text { Az etnográfiai } \\
\text { tudás } \\
\text { konstrukciójában } \\
\text { a Másiknak } \\
\text { tulajdonított, } \\
\text { egyre fontosabb } \\
\text { szerep } \\
\text { artikulációja }\end{array}$} & & & & & - & \\
\hline & $\begin{array}{l}\text { Munkatárs } \\
\text { (coworker) }\end{array}$ & & & & \multirow{3}{*}{$\begin{array}{l}\text { hermeneutikai / } \\
\text { interpretív }\end{array}$} & & $\begin{array}{l}\text { klasszikus } \\
\text { interaktív }\end{array}$ & $\begin{array}{l}\text { Bateson, } \\
\text { Mead }\end{array}$ \\
\hline & $\begin{array}{l}\text { Beszélgetőtárs } \\
\text { (discussant) }\end{array}$ & & & & & \multirow{2}{*}{$\begin{array}{l}\text { posztmodern / } \\
\text { dialogikus / } \\
\text { interaktív }\end{array}$} & $\begin{array}{l}\text { interpretív / } \\
\text { diszkurzív }\end{array}$ & Geertz \\
\hline & $\begin{array}{l}\text { Szerzőtárs } \\
\text { (coauthor) }\end{array}$ & & & & & & kollaboratív & Lassiter \\
\hline
\end{tabular}

A Másik hivatkozására használt alapvető fogalmak az etnográfiában

55 .

A táblázat rövid áttekintése azt az érzést kelti, hogy az általunk elemzett kapcsolatot a másik aspektusából nézve is valami, a Paerregaard által leírt változás / fejlődés mutatkozik meg. Amíg a vadember a totálisan idegent jelöli, addig a szerzőtárs már azt a másikat, aki velünk szemben áll, és más ugyan, mint mi, de egy közülünk, legalábbis a közös ügyünk összefüggésében mindenképp. A - kulturális és interpretációs értelemben vett - szöveghez való viszonyunk teljesen szimmetrikusnak tünik, sőt, a Másikra a saját terminológiai rendszerünkben használatos ki- 
fejezéssel (szerző) hivatkozunk. Ennek talán ellentmond az, hogy a vadember kifejezés is a saját terminológiánk része, csakúgy, mint a primitív. Van ugyanakkor a terminológiának egy gyakorlatilag állandó eleme, mely végigkíséri az etnográfia történetét, ez pedig az a szokás, hogy a Másikra annak - jobbára - önmegjelölésével hivatkoznak. Ez pedig talán interpretálható úgy, mint a Paerregaard által felvázolt három kategória közül az első ( $a$ másfajta) párhuzama. 56.

Ez a probléma azért fontos most számunkra, mert e hipotézis mentén valamelyest rendszerezhetővé válnak az etnográfia újabb fejleményei, melyek máskülönben inkább zavart, bizonytalanságot okoznak. A „bennszülöttek” ma már egyáltalán nem annyira passzív kiszolgálói az etnográfusoknak, mint korábban (bár lehet, hogy korábban sem voltak azok, csak ezzel kapcsolatos információkat nem nagyon rögzítettek az etnográfusok). A hosszú folyamat a kognitív antropológiához nyúlik vissza az 1950-es évek tájára, amikor elkezdték a korábbi „adatközlőt” „bennszülött munkatárs”-nak, „konzulensnek” vagy „,szaktanácsadónak” (consultant) nevezni. A konzulens olyan „bennszülött” gondolkodó társ, aki az etnográfussal együtt vállalkozik arra, hogy kidolgozza, illetve felfejtse a bennszülött gondolkodás és kultúra kategóriáit, kapcsolatainak és jelentéseinek rendszerét (Lassiter 2005:25-48). A Másik alárendelt, információközlésre korlátozódó szerepe („arra felelj, amit kérdeztek”) tehát megszűnt, s olyan közremüködője lett a kutatásnak, aki egyenrangú félként szól bele az értelmezésbe, és nem csupán adatot közöl, de maga is kér (sôt elvár) bizonyos adatokat, sokszor a kutatás olyan eredményeit, melyeket saját életében hasznosítani tud. Az adatközlő, a Másik, a vietnami őserdő mélyén maga is kamerás mobilt ragad és „visszalő” az őt fotózó kutatóra [25]. A helyi újság, egy bennszülött aktivista blogja beszámol a kutatásról, s megpróbálja kontrollálni is azt. Végül pedig: az a tendencia, melynek végén jelenleg a kollaboratív etnográfia áll, sok kutató számára az etnográfia elbizonytalanodását jelenti, hiszen például a diszciplína „fénykorát” jelentő, a terepmunka paradigmáját kidolgozó Malinowskiéra átfogó értelmezéseket és monografikus müveket létrehozó magabiztos szemléletéhez képest a kortárs etnográfia „megszeppent kisfiúnak” túnik. Ha az előbbi Gulliver (mint sokszor mondják), akkor az utóbbi inkább Alice (Csodaországban). Vagyis az etnográfus pozíciója a „terepen” nagyon labilissá vált, korábbi attribútumai (jegyzetfüzet, fényképezőgép, az ember, aki finom embereket bárgyú kérdésekkel gyötör (lásd Geertz 2001b:224) nem egyértelműek, s különböző jogi és etikai megfontolásokból korábbi hatalmi pozícióját is kénytelen feladni (bár ezt legtöbb esetben nem kényszerüségként éli meg), sőt arra kell törekednie, hogy hagyja szóhoz jutni a „terep hangját”. Mindezt lehet veszteségként, pozícióvesztésként értékelni, de ennek a hipotézisnek a mentén - talán - meg lehet kísérelni egy összefüggő, logikus folyamatként is láttatni.

Ennek az együttmúködésen, kollaboráción alapuló, és az etnográfus megváltozott pozíciójára is reflektáló kutatásnak mára az antropológiában számos irányzata alakult ki [26]. A Luke Eric Lassiter által kollaboratív etnográfiának nevezett módszer például ennek a „beleszólásnak”, vagyis a kutató és a kutatottak egyenrangú együttmúködésének több szintjét határozza meg. Azt látja igazán kívánatosnak, ha a partnerek a kezdetektől, vagyis kutatási téma kijelölésétől részt vesznek a folyamatban, hiszen így olyan tevékenységek kerülnek az etnográfiai terepmunka fókuszába, melyek egyértelmúen fontosak a helybéliek számára, s ezért érdekeltek és motiváltak lesznek a kutatásban való közreműködésben, ami vélhetően azt eredményezi, hogy nem „vezetik meg” a kutatót, és ténylegesen használt problémamegoldó felkészültségeiket mozgósítják a folyamat során. Lassiter (2001b) tehát 
úgy véli, az etnográfus nem a bennszülött válla felett kukucskál, hanem mellette áll és vele egy irányba néz, s közben nem csupán beszélget vele a látottakról, hanem a beszélgetés eredményeit együtt - különböző módszerekkel megvalósuló 58. együttmüködés - eredményeként közös szerzőség alatt hozzák nyilvánosságra.

3•3. A közös szerzőség kérdése végül átvezet bennünket a változások harmadik fontos területére, ami az etnográfiai írás gyakorlata, és az ilyen szövegek mibenlétéről való gondolkodás. Az írás az antropológus alapvető reakciója a terepmunkára, folyamatosan jelen van a tárgyak és egyebek - például fényképek - gyüjtésével együtt, intenciója azonban változik. Az etnográfia „hagyományos” modellje szerint az adatközlő-etnográfus-olvasó kapcsolat középpontjában az etnográfus áll. Ố az, aki kapcsolatot teremt a „bennszülöttekkel” s aki azután valamilyen kapcsolatot teremt az olvasókkal. Az olvasók és bennszülöttek ebben a modellben egymásról szinte csak az etnográfuson keresztül szereznek ismereteket, közvetlenül csak elvétve és rendszertelenül. Az etnográfus felé mindkét oldalról szintén ritka a visszacsatolás. Az Etnográfus, Bennszülött, Olvasó ebben a modellben olyan címkék, melyek a tudáshoz - és egymáshoz - való viszony tekintetében, illetve az etnográfiában, mint kommunikációs folyamatban rögzített szerepeket jelölnek. A kollaboratív modellekben azonban ezek a szerepek nem feltétlenül rögzítettek. A kérdező - kérdezett - címzett szerepek leválhatnak az Etnográfus - Bennszülött Olvasó szereplőkről és új párosítások jöhetnek létre, az etnográfiai írás, vagyis a „produktum” pedig a köztük lévő interfész szerepét töltheti be, abban az értelemben, hogy egyrészt kapcsolatot teremt közöttük, másrészt pedig megteremti a közös kód létrehozásának - tikkek, kacsintások és egyéb szemhéjgyakorlatok értelmezésének - lehetőségét. Ehhez azonban jelentős mértékben újra kell gondolni az antropológia íráshoz való viszonyát.

59.

A korai, mindent összegyưjtő - vagy épp a kultúra funkcióiról vagy egész struktúrájáról - értekező antropológia számára fontos volt az átfogó, monografikus írások megalkotása. Totális értelmezéseket akartak adni, kivált az evolucionista irányzatok képviselői, nem is csak egyes kultúrákról, de általában a Kultúráról. Ettől az intenciótól elmozdulva, ahogy fentebb erról szó volt, mára elsődlegessé az antropológus jelenlétének bemutatása vált, ez adja a kutatás hitelességét. 60.

Az átfogó, totális leírások feladása egy másik következménnyel is járt, ami gyakorlatilag folyamatosan jelen volt a Malinowski-féle paradigmában, csak el kellett telni egy viszonylag hosszú időnek, mire reflektált rá az antropológia. Malinowski hatalmas jelentőséget tulajdonít a terepnaplónak. Az etnográfusnak szerinte mindent le kell írni. Ennek egyik oka a már tárgyalt módszertani átláthatóság és tudományos megbízhatóság, vagyis a kutatás csak akkor lesz megbízható, ha az olvasó egyértelműen látja, hogy a következtetéseit milyen adatokból vonta le a kutató (Malinowski 2000:44). A teljes lejegyzés másik oka a kutató memóriájának támogatása, hiszen megeshet, hogy valami elkerüli a figyelmét, s a jegyzetei ismét és újból történő átnézése ismeretei bővülése során segítenek komplexebben látni a vizsgált társadalmat. (Malinowski 2000: 50) Végül a fáradhatatlan totális jegyzetelés, minden eseménynek, jelentősnek és jelentéktelen apróságnak a megörökítése segít abban, hogy összeálljon a rendszer és minden a helyére kerüljön benne (Malinowski 2000: 50), ami pedig nincsen lejegyezve, az megeshet, hogy kimarad ebből a totalitásból, így ami nincsen lejegyezve, az olyan, mintha nem is lenne: nem alapozható rá következtetés, lehet, hogy eszébe sem jut a kutatónak és így hi- 
ányozni fog a struktúrából. A napló tehát lényegében számára a tapasztalat reflexióján keresztül a tapasztalatot rekonstruálja, s lehetőséget ad annak értelmezésére is. A rekonstrukció persze sosem teljes (nem is lehet az) és mindig értelmező rekonstrukció, vagyis sosem azt adja vissza, amilyen a terep valójában, hanem azt, ahogyan a kutató a terepet megtapasztalta. Az antropológusok ezért is vetették el késóbb a totális lejegyzés ideáját.

61.

A totális értelmezés azonban etikai problémákat is felvet, és ezekre reflektál a posztkolonialista krízisen áteső antropológia, amikor felismeri, hogy a bennszülött kultúrák antropológiai értelmezése lényegében egyfajta kisajátítás volt, s erre azzal reagál, hogy az antropológiai értelmező elbeszélésbe az antropológus mellett bevonja a bennszülötteket is. Ez nem csak annyit jelent, amit a kollaboratív módszerek összefüggésében fentebb írtam, hanem azt is, hogy az etnográfiai szövegek „monodikus” zártsága elkezd feloldódni, s a lehetséges írásmódok közé bekerülnek az interaktív, „polifón” formák. Az etnográfiák általában zárt szövegek (sok esetben még a kollaboratív munkák is), vagyis egyrészt a kutatás végeztével, az összefoglaló publikációk megjelenését követóen a szöveg nem épül tovább. Másrészt az olvasónak nincs lehetősége visszaszólni, nincs visszacsatolás, és a szövegek nem élnek együtt a problémákkal, melyeket feldolgoznak, interpretálnak. 62.

A sürú leírás lényege, mint láttuk, a kultúra értelmező leírása, ami a gyakorlatban úgy néz ki, hogy a leírás - adatközlés - interpretáció - szövegrétegei fedésbe kerülnek, és mint az additív színkeverés fénynyalábjai, alakítják ki a vizsgált társadalmi jelenség szövegben megjelenített képét. A sűrü leírás célja az értelmezés; a társadalmi beszédfolyamat értelmezése; ami abból áll, hogy a beszéd jelentését megpróbáljuk kiszabadítani esetleges körülményeiból, illetve tanulmányozható formában rögzítjük - gyakorlatilag azzal, hogy a beszélők szempontjából releváns felkészültségeket integráljuk a szövegbe. Geertz a sürủ leírásról szóló tanulmányában mint tényt rögzíti azt a helyzetet, hogy az antropológiai elemzés, az értelemteli struktúrák egymásra vonatkozásának feltárása mindig befejezetlen, sosem lezárható folyamat (Geertz 2001b:223-224) - s bár ő erre egyáltalán nem tér ki, a kulturális elemzésnek ez a sajátossága nyilvánvaló ellentmondásban van az elemzés médiumának természetével. A társadalmi beszédfolyamat, melyet elemez ugyanis változhat, $\mathrm{s}$ ezt a változást a rögzített struktúrájú nyomtatott szöveg nem képes követni. Ez persze nem is feltétlenül célja, hiszen a kula sem létezik már, Malinowski elemzése viszont a kuláról ettől függetlenül létezik és érvényes etnográfiai munka - írja Geertz. Az antropológiában nem az időszerüség, a történés jelenidejűsége követelmény, hanem az etnográfus jelenléte a történésben (már feltéve, hogy nem történeti antropológiáról van éppen szó). Ez azonban nem biztos, hogy az antropológia lényegéből fakadó sajátosság, hanem könnyen lehet, hogy az antropológiai írás médiumának természetéból következik. Geertz egy lábjegyzet erejéig kitér erre a problémára, s megjegyzi, hogy „a bemutatási módok tudata (nem is beszélve a velük végzett kísérletekről) igencsak hiányzik az antropológiából” (Geertz 2001b:213) ennél mélyebben azonban nem foglalkozik a kérdéssel. 63.

Az új, interaktív módszerek, az interaktív hipermédia, a web2 és hasonló technikai eszközök és lehetőségek viszont megoldást nyújthatnak a rögzített szerkezetű és lezárt szövegek problémájára, vagy legalábbis lehetőséget adhatnak arra, hogy a megjelenítésnek ezekkel az új lehetőségeivel kísérletezzünk [27]. 
64.

Egy interaktív hipermediális rendszer ugyanis a hipermédia adatintegrációs lehetőségeiből következően képes arra, hogy egy kutatás összes anyagát digitális (digitalizált) formában egy helyen tárolja, különböző módokon elérhetővé tegye és egymással különböző módokon össze is kösse. Ez a lehetőség nem csupán a Malinowski-féle totális jegyzetelés roppant gazdaságos és mobilizálható megvalósítása, de annak jelentős kiterjesztése is, hiszen az adatok és információk összekapcsolása - akár automatizált módokon, algoritmusok alapján akár a kutató által a kódolásvisszanyerés különböző módszereit alkalmazva - az anyag rendszerezésének, kategorizálásának roppant hatékony és többrétegű módszerét jelenti. Ezen túl azonban a rendszer a terepmunka során gyüjtött, ráadásul különböző mediális természetű adatokat nem csupán egymással, de a terepmunka eredményeit közlő szövegekkel is közvetlenül összekapcsolhatja, így az adatok és az értelmezések - ismét Malinowski elképzelését megvalósítva - a lehető legközelebb kerülhetnek egymáshoz.

65.

A különböző mediális természetű (szövegek, álló- és mozgóképek, hanganyagok) integrálása és összekötése, kivált úgy, hogy azok többnyire egy közös képernyőn jelennek meg, az elemzés komplexitását is növeli. 66.

Azok a technológiák, melyeket felhasználói szinten a különböző közösségi oldalakról vagy a közösségi hozzájárulással fejlesztett tudásbázisokból ismerünk, az etnográfiai projektekben is alkalmazhatóak, s így lehetővé teszik egyrészt az etnográfiai terep színtereinek, másrészt a terepen alkalmazott kollaboratív módszereknek a kiterjesztését például az online térbe. Ezeket a módszereket a cyberetnográfia egy ideje már sikeresen alkalmazza, ugyanakkor a módszer sokkal több lehetőséget rejt, hiszen segítségével egyrészt hibrid (online és onsite színtereken követett problémák vizsgálatára tervezett) terepmunkák is végezhetőek, illetve az interaktív hálózati környezetben végzett kollaboratív terepmunka összekapcsolható a kutatás integrált adatbázisával is.

67.

Egy ilyen rendszer tehát lehetőséget ad egyrészt a kollaboratív módszerek eredményeit közlő, a közösségi konszenzust tükröző, (akár reprezentatív-érdekérvényesítő) szövegek megjelentetésére, ugyanakkor arra is, hogy a kisebbségi különvélemények a többségivel párhuzamosan - épp ezek torzító hatását ellensúlyozandó, illetve ezek reprezentációs és érdekérvényesítési stratégiáit felfedve és értelmezve - megjelenjenek. Ez a „demokratikus” jelleg pedig, ami jó eséllyel küszöböli ki azt, hogy a folyamat bármelyik résztvevője kisajátítsa az értelmezés lehetőségét, az etikai probléma kiküszöbölésével ismét visszafordítja az etnográfiai leírást a Malinowski által szorgalmazott totális rögzítés elképzelése felé. 68.

Végül, de nem utolsó sorban egy ilyen rendszer a folyamatos újrakutathatóság lehetőségének fenntartása mellett arra is lehetőséget ad, hogy a kutatók és a helybéli konzulenseik a változásokat is kövessék, és mindig új és új adatokkal, illetve értelmezésekkel bővítsék azt. A változások mechanikus rögzítése és visszakereshetősége, a korábbi állapotok rekonstruálhatósága, a különböző értelmezők és értelmezési szintek azonosíthatósága és összekapcsolhatósága, illetve az adatok és interpretációk kapcsolatának explicit jellege, a sürü leírás középpontjában álló értelemteli struktúrákat és egymásba érésüket egyszerre teszi átláthatóbbá és komplexebbé - vagyis mindez talán már a [SürüLeírás 2.o]. 


\section{4. Összegzés \\ 69.}

A leírtakból reményeim szerint egyértelmúen látszik, hogy az antropológia módszertana nagyon sokféle és nagyon széttartó [28]. „Sokféle könyv született már az antropológiai kutatás módszertanáról (...), de valamennyi csak a gyakorlat elméletét képes leírni. Mert a gyakorlat maga a terepmunka, ami mindig más, mert minden terep, minden közösség és minden kutató más. Ezért aztán nincsen olyan egységes terepmunka-módszer, amely sablonszerúen alkalmazható bármilyen terepen, bármely nép kutatásakor. Minden egyes terepnek megvannak a maga speciális problémái, sajátos megközelítési lehetôségei. Így elsősorban az adott helyzet és a sajátos körülmények, a helyi adottságok alapján határozhatjuk meg a legcélravezetốbb, legjobban alkalmazható kutatási módszert, természetesen az alapos megismerés, alkalmazkodás és befogadás után. Ahogyan Boglár Lajos fogalmazott, »nincsen olyan kulcs, amelyik minden zárat nyit, mert amelyik mindenre jó, az csak álkulcs lehet «” (Kisdi 2012:35).

\section{JEGYZETEK}

1 Van némi vita vagy legalábbis eltérés abban, hogy a különböző társadalomtudományok, illetve különböző tudományos tradíciók hogyan határozzák meg az etnográfia fogalmát. Magyarországon az etnográfia alatt, többnyire mint annak tükörfordítását, a néprajzot szokás érteni, ami alapvető́en a magyar népi kultúra tanulmányozását jelenti, szemben az etnológiával, mely kifejezéssel az Európán kívüli népek tanulmányozására utalnak. (Ez persze nem jelenti azt, hogy ne létezne az európai etnológia fogalma. Lásd Kaschuba 2004) Ez azután számos félreértésre ad okot, hiszen a német, brit, az amerikai vagy a francia terminológia ettől eltérő. Ez a bizonytalanságot rejtő szóhasználat talán azért is rögzült, mert a hazai tudománytörténet egy bizonyos szakaszában némileg enyhítette a frissen intézményesülő kulturális antropológia és a néprajz közti feszültséget. Talán ebből is következik, hogy Clifford Geertz Sürü leírás címú tanulmányának azt a gondolatmenetét, melyben a szerző az antropológia múvelése felől közelíti meg annak mibenlétét, s azt írja, hogy „In anthropology, or anyway social anthropology, what the practioners do is ethnography." (Geertz 1973: 5.) az 1994-ben - vagyis az antropológia magyarországi intézményesülésének kezdetén - megjelenő magyar kiadásban a fordító a következőképpen adta vissza: „Az antropológia vagy legalábbis a szociálantropológia müvelői néprajzot írnak.” (Geertz 2001a:196.) A geertzi gondolat az amerikai közegben viszont egészen máshogy hat, hiszen ott az etnography/etnográfia az antropológia egyik nagy területe, $\mathrm{s}$ a gyakorlati kutatást értik alatta, míg az ethnology terminussal az antropológiai elméletalkotás tevékenységére utalnak. Ezzel szemben Claude Lévi-Strauss számára az etnográfia a terepmunkától az interpretációig tartó egész munkafolyamatot jelöli (Kisdi 2012: 26.) míg Tim Ingold (Ingold 2007) egyik tanulmányában éppen amellett érvel, hogy az antropológia nem etnográfia, a kettőt egészen más megismerési módok jellemzik, s ezért egyértelmüen meg kell azokat különböztetni.

2 Az antropológiával és a terepmunkával kapcsolatos, a tudományos közegben is élő közhelyekkel foglalkozik nagyon élvezetes módon Barley 2006.

3 A teljesség igénye nélkül a terepmunkával átfogóan foglalkozó írások: Borsányi 1988, Fél 1991, Hollós 1995, Kunt 2003, Feischmidt 2006, Ispán - Magyar - Mészáros - Vargyas 2016, Ispán - Magyar Mészáros - Vargyas 2017.

4 Tanulmányomban nincsen mód arra, hogy részletesen kitérjek az antropológiai kultúrafogalom kialakulására, történetére. A kérdéshez bővebben lásd Stocking 1966, Yengoyan 1986, Elias 1987, Márkus 1992, Kroeber - Parsons 1994, Geertz 2000, Fox - King 2002, N. Kovács 2007.

5 1832. október 2. - 1917. január 2.

6 Ma British Science Association. Az ajánlás kiadását 1949-ben a Royal Anthropological Institute vette át. A hatodik, átdolgozott kiadást ók adták ki 1951-ben, s ezt a verziót jelentették meg 1971-ig. Ezt követően már inkább az eredeti kiadás tudománytörténeti reprintjei jelentek meg. 
7 „For the use of travellers and residents in uncivilized lands.”

8 Ez a struktúra a későbbi kiadásokban jelentősen változott. Az 1951-es utolsó kiadásban a szerkesztók a hangsúlyt már a terepmunka módszertanának részletezésére helyezték, $\mathrm{s}$ nem is konkrét kérdéseket fogalmaztak meg az etnográfusok számára, hanem a kutatás-megfigyelés fontos témáira irányították rá a figyelmét. Így számozott kérdésekkel itt már nem, vagy csak elvétve találkozunk.

9 A 19. század végén és a 20. század első felében több hasonló kérdőív született. Ilyen volt az Amerikai Egyesült Államokban, a Smithsonian Institution keretében múködő, 1879-ben alapított Bureau of Ethnology - mely 1897-től Bureau of American Ethnology néven gyüjtötte az amerikai őslakosokkal kapcsolatos valamennyi kutatási adatot - által kidolgozott és rendszeresített kérdőív. Ilyennek tekinthető az a kérdőív is, melyet a Magyar Néprajzi Atlasz 1933-tól tervezett, majd végül 1959-1969 között lezajlott adatgyüjtéséhez dolgoztak ki - jóllehet ebben az esetben „a gyüjtést szakképzett etnográfusok széles köre végezte" (Ortutay 1980:491-492) s nem utazók, papok és egyéb múkedvelók.

10 A jelen tanulmány keretei nem teszik lehetôvé, hogy az amerikai, francia vagy német társadalomtudomány összefüggéseiben is megvizsgáljuk ezt a kérdést, ám mivel ez nem is tartozik szorosabban vett tárgyunkhoz, itt csak jelzem, hogy ezek többé vagy kevésbé eltérő képet mutatnak.

11 Tulajdonképpen ebbe a keretbe illeszthető a magyar népi kultúra, mint a nemzeti kultúra ősforrásának „felfedezése” vagy a keresztény misszionáriusok által Európába küldött képekből és tárgyanyagból rendezett „missziós kiállítások” jelensége is. Utóbbiak elsődleges célja az volt, hogy tevékenységük - s az annak fókuszában álló idegen kultúra - bemutatásán keresztül a missziós társaságok számára segítsenek támogatókat szerezni. Mivel azonban a misszió többnyire nem csupán a keresztény hit, hanem nyugati civilizáció terjesztését is célul tűzte ki, s mindezt egy gyarmati infrastruktúrán végezte, a kiállítások ezeknek az összefonódó céloknak a legitimációjában és ezzel együtt az európai modern identitás megerősítésében is fontos szerepet játszottak. Lásd Gebauer 2018; Bosch 2005.

12 Kroeber és Kluckhohn ezzel szinte éppen ellentétesen azt jegyzi meg, hogy Boas jóllehet kiterjesztette és finomította Tylor fogalmát, de nem tört ki annak keretek közül. Meglátásuk szerint Boas találkozott Tylorral, aki magától értetődő módon befolyásolta gondolkodását, és ezt a befolyást Boas tanítványaira is örökítette (Kroeber - Kluckhohn 1952:45).

13 A plurális következetes használata ugyanakkor csak tanítványai első generációjának szövegeivel terjedt el. Boas fogalomhasználatának konfúz volta ezzel együtt világosan jelzi, hogy munkássága átmenetet jelent a kultúra antropológiai fogalma felé.

14 Malinowski eredetileg lengyelül, új-guineai terepmunkája alatt írt személyes naplóját az antropológus hagyatékát feldolgozó tanítvány, Raymond Firth találta meg, majd húsz évvel Malinowski halála után, 1967-ben özvegye adta ki, némiképp cenzúrázva (Bronislaw Malinowski: A Diary in the Strict Sense of the Term. New York: Harcourt 1967). A napló megrázta a Malinowski-paradigmán felnőtt, s azt etalonnak tartó antropológus társadalmat, mert - mint a magyar fordítást jegyző Zentai Violetta megjegyzi - „a naplóbejegyzések arról tudósítanak, hogy milyen gyötrelmeket, kétségeket, bizonytalanságokat kellett a résztvevő megfigyelés módszere atyjának kiállnia. E gyötrelmek nemcsak egy öntelt, ámde sebezhető ember karakterére vetnek fényt, de jól illusztrálják a résztvevő megfigyelés tudományos módszerének törékenységét is. Malinowski új-guineai kutatásai során nem tudott megfelelni a saját maga által felállított normáknak és az elképzelt szuperantropológus képének, s ez így természetes. Valetta Malinowski nagy tévedésben hagyta volna a világot, ha a naplót s annak titkait örökre elrejti” (Malinowski 2001:91). A napló a közlését követő intenzív vitákon keresztül így jelentős mértékben hozzájárult a terepmunka megújításához, és a terepen kutató antropológus szerepeinek újraértékeléséhez.

15 Ehhez hasonló az a felismerés is, hogy az antropológus tevékenyen részt vesz a kutatott „másik”, az idegen létrehozásában, konstrukciójában, vagyis nem „megtalálja” az idegent, hanem megkonstruálja azt. Ezt nevezi a szakirodalom az „othering” jelenségének.

$16 \mathrm{Az}$ emberi viselkedés illékony példáiban megjelenő kultúrával foglalkozó etnográfus gondolata felidézi Malinowskit, aki szintén a matériák legképlékenyebbikében, az emberi lényben megtestesülő kultúra vizsgálatáról írt (Malinowski 2000:48-49). Az ilyen találkozási pontok kapcsán veti fel Renée Sylvain, hogy érdemes újragondolni a (poszt)modern antropológia Malinowskihoz füződő viszonyát, hiszen egy alaposabb elemzés után könnyen kiderülhet, hogy legalább olyan mértékű kontinuitásról beszélhetünk, mint amilyen mértékű különbségről, elsősorban önmaguk definiálása okán az utóbbiak beszélnek (Sylvain 1996). 
17 Csábító lenne ezen a ponton tovább elemezni Talcott Parsons és Max Weber hatását is Geertzre. Abban ugyanis, ahogy Geertz a vallást, ideológiát, a múvészetet és a józan észt kulturális, vagyis a társadalomban jelentésközvetítő és -rögzítő rendszereként értelmezi, egyértelmü a szociológus Parsons hatása. Geertznél azonban ezek a kulturális rendszerek olyan - ricoeuri értelemben vett - sajátos szemiológiai rendszerek, melyek értelmezési környezetként meghatározzák a kereteik közt folyó társadalmi kommunikáció különböző szintjein lévő tipikus viszonyokat. Parsons azért is fontos Geertz számára, mert ő ismertette meg vele Max Weber munkásságát, akinek megértő - interpretív - szociológiája Geertz antropológiájának ihletője is lett. Weber a kutatás hangsúlyát a mások viselkedésével számot vető és ahhoz igazodó emberek cselekvéseinek értelmezésére helyezi (Weber 1967: 41), s ezt az értelmezést úgy hajtja végre, hogy a cselekvéseket a cselekvő környezete által azoknak tulajdonított jelentések komplex hálójába helyezni. (Keyes 2002) Geertz talán leghíresebbé vált, a következőkben bemutatott kultúradefinícióját Weber ezen gondolataira való hivatkozással vezeti be. Parsons és Weber hatásának hosszabb elemzése azonban nagyon messzire vinne témánktól.

18 Geertz módszeréről sokszor kritikusan megjegyzik, hogy az közelebb áll az irodalomhoz, mint a tudományhoz. Ố maga ennek a problémának a megoldását a módszer nagyon konzekvens alkalmazásában látja. Mint írja: „megpróbálom a szimbolikus formák értelmezését, amilyen szorosan csak lehet, konkrét társadalmi eseményekhez és alkalmakhoz, a köznapi élet nyilvános világához kapcsolni, s oly módon szervezni, hogy az elméleti megfogalmazások és a leíró értelmezések közötti kapcsolatokat ne homályosítsák el a sötét tudományokra való hivatkozások. [...] A kultúra szemiotikus felfogását semmi sem járatja le gyorsabban, mint az, ha megengedjük, hogy az intuíció és az alkímia egyfajta keverékévé alakuljon - bármilyen elegánsan fejeződjenek is ki az intuíciók, és bármilyen korszerú kinézetet kölcsönözzenek is az alkímiának" (Geertz 2001b:225).

19 A kultúra kifejezés „a szimbólumokban megtestesülő jelentések történetileg közvetített mintáit jelöli, a szimbolikus formákban kifejezett örökölt koncepciók azon rendszerét, amelynek segítségével az emberek kommunikálnak egymással, állandósítják és fejlesztik az élettel kapcsolatos tudásukat és attitüdjüket” (Geertz 2001a:74).

20 Ebből persze arra a korántsem meglepő következtetésre juthatunk, hogy a használt és „,vallott” kultúrafogalom és az alkalmazott terepmunka módszertan összefüggése egy-egy kutató életművében jóval összetettebb és dinamikusabb annál, mint amire a megjelent múveik alapján következtetünk, s valószínúleg nem úgy pattan ki, tökéletes fegyverzetben a fejéből, mint Pallas Athéné Zeuszéból. Ezek a koncepciók együtt alakulnak, változnak, érnek, csak ez a folyamat többnyire nem jelenik meg az antropológusok írásaiban. Ebből a szempontból is tanulságos olvasmányt jelentenek a zöldfülú antropológus, Nigel Barley feljegyzései a sárkunyhóból (Barley 2006).

21 Saját terepei közül Marokkó például e tekintetben határeset, sőt Margaret Mead és Gregory Bateson már az 1930-as évek végén azt érzékelteti Baliról, Geertz terepmunkáinak másik fontos helyszínéról, hogy egyáltalán nem mutatja a nyugati civilizációtól érintetlen kultúra képét. (Lásd Mead - Bateson 1942).

22 Nem is beszélve arról, hogy a hazatérő antropológusok sokszor fordulnak a nyugati társadalom „belső egzotikumai”, vagyis a posztmodern társadalomban, de nem modern társadalomszerveződési minták szerint élő csoportok felé. (Ehhez lásd Bausinger 1989.)

23 Itt érdemes talán használni az etnográfiában a rokonsági terminológia-kutatásban használatos megkülönböztetést az egyazon személy összefüggésében használatos megnevezés, megszólítás és hivatkozás között! Utóbbi mindig az adott személyre egy harmadik féllel történő párbeszédben való hivatkozást jelöli, s mint ilyen, erősen kontextusfüggő.

24 A táblázat - késóbbi kiegészítésig - csak az alapvető fogalmakat tartalmazza, így nincsen benne például a marginális „interjúalany” kifejezés.

25 Vargyas Gábor szíves közlése alapján.

26 Tanulmányomnak nem célja ezek részletes ismertetése, s miután egy (át)alakuló diszciplináris mezőről van szó, az egymással különböző kapcsolatban lévő tudományágak és gyakorlatok rendszeres áttekintése meg is haladná annak kereteit. A különböző neveken megjelenő és különböző, de egymással legalábbis rokonságot mutató, s ugyanakkor más társadalomtudományokkal is szoros kapcsolatot ápoló antropológiai irányzatokban többnyire közös, hogy feladják a be nem avatkozó antropológia esz- 
ményét, és többé vagy kevésbé, de részesévé válnak a kutatott társadalmak átalakulási illetve érdekérvényesítő folyamatainak. Ezt a részesedést (participációt) többnyire a közösségfejlesztés (community development) talán legfontosabb alapelve, a képessé tétel (empowerment) határozza meg, vagyis a részvétel célja nem az, hogy megoldják a közösség problémáit, hanem az, hogy a közösség belső erőforrásainak feltárását segítő folyamatokon keresztül hozzájáruljanak ahhoz, hogy a közösség maga oldja meg ezeket a problémákat. Az akció-, részvételi-, kollaboratív és alkalmazott kifejezések különböző kombinációjával jelzett antropológiák útvesztőjében kiváló eligazítást ad a Replika folyóirat 2016-ban megjelent 100., Lajos Veronika és Farkas Judit által szerkesztett száma, illetve a szám Lajos Veronika által jegyzett bevezető tanulmánya (Lajos 2016).

27 A témához bővebben lásd a Replika folyóirat 90-91. számának írásait, valamint Nagy (2015) és Nagy (2018).

28 Az utolsó fejezetben nem szóltam a kortárs kultúrafogalomról, s ez szándékos, tekintettel arra, hogy jóllehet a módszertan változik, a széttartás olyan mértékư, hogy a változó módszertanok mögött nehéz lenne egy - vagy több - széles körben érvényes és elfogadott kultúrafogalmat felmutatni.

\section{IRODALOM}

APPADURAI, ARJUN

2001 A lokalitás teremtése. Regio 12(3):3-31.

[BAAS] BRITISH ASSOCIATION FOR THE ADVANCEMENT OF SCIENCE

1874 Notes and Queries on Anthropology. London: Edward Stanford.

BAKOS ÁRON

2015 A kultúra fogalma Franz Boas munkásságában. Erdélyi Múzeum 77(2):128-138.

\section{BALOGH BALÁZS}

2017 A néprajzi terepmunka kérdései. In Ethno-lore, A Magyar Tudományos Akadémia Bölcsészettudományi Kutatóközpont Néprajztudományi Intézetének Évkönyve XXXIV. Ispán Ágota - Magyar Zoltán - Mészáros Csaba - Vargyas Gábor, szerk. 9-12. Budapest: MTA BTK NI.

BARLEY, NIGEL

2006 Egy zöldfülű antropológus kalandjai. Feljegyzések a sárkunyhóból. Budapest: Typotex.

\section{BATESON, GREGORY - MEAD, MARGARET}

1942 Balinese Character. A Photographic Analysis. New York: New York Academy of Sciences.

\section{BAUSINGER, HERMANN}

1989 Párhuzamos különidejüségek. (A néprajztól az empirikus kultúratudományig). Ethnographia 100(1-4):24-37.

1995 Népi kultúra a technika korszakában. Budapest: Osiris-Századvég.

BOAS, FRANZ

1930 Anthropology. In Encyclopedia of the Social Sciences, 2. köt. Seligman, Edwin R. A., editor-in-chief. 73-110. New York: Macmillan.

1938 The Mind of Primitive Man. Revised Edition. New York: Macmillan.

BOHANNAN, PAUL - GLAZER, MARK, ED.

1997 Mérföldkövek a kulturális antropológiában. Budapest: Panem.

BORSÁNYI LÁSZLÓ

1988 A megfigyelési technikák az etnológiai terepmunkában. Ethnographia 99(1):58-87.

BOSCH, DAVID J.

2005 Paradigmaváltások a misszió teológiájában. Budapest: Harmat Kiadó. 


\section{DIANTEILL, ERWAN}

2012 Cultural Anthropology or Social Anthropology? A Transatlantic Dispute. L'Année sociologique 62(1):93-122. https://doi.org/10.3917/anso.121.0093

ELIAS, NORBERT

1987 A civilizáció folyamata. Szociogenetikus és pszichogenetikus vizsgálódások. Budapest: Gondolat.

\section{FEISCHMIDT MARGIT}

2006 Kvalitatív módszerek az empirikus társadalom és kultúrakutatásban. Szabadbölcsészet Internetcím: http://mmi.elte.hu/szabadbolcseszet/mmi.elte.hu/szabadbolcseszet/ index4b47.html?option $=$ com tananyag\&task $=$ showElements\&id tananyag $=53$ (Letöltés: 2019. 07. 20.)

\section{FÉL EDIT}

1991 A saját kultúrájában kutató etnológus. Ethnographia 102(1-2):1-8.

FOX, RICHARD G. - KING, BARBARA J., ED.

2002 Anthropology beyond culture. New York: Berg. https://doi.org/10.4324/9781003084631

\section{FREEMAN, DEREK}

1998 The Fateful Hoaxing Of Margaret Mead: A Historical Analysis Of Her Samoan Research. New York: Basic Books.

\section{GEBAUER HANGA}

2018 Hittérítés fényképeken - távoli kultúrák másodkézból. Missziós fotográfiák az európai befogadó szemével. Korall 73:44-78.

\section{GEERTZ, CLIFFORD}

1973 Thick Description: Toward an Interpretive Theory of Culture. In Geertz, Clifford: The Interpretation of Cultures. 3-30. New York: Basic Books.

2000 Kultúrák. Magyar Lettre Internationale 38: online: http://www.c3.hu/scripta/lettre/lettre38/geerz.htm (Utolsó letöltés: 2019. április 25.)

2001a A vallás mint kulturális rendszer. In Geertz, Clifford: Az értelmezés hatalma. Antropológiai írások. 63-103. Budapest: Osiris Kiadó.

2001b Sűrű leírás. Út a kultúra értelmező elméletéhez. In Geertz, Clifford: Az értelmezés hatalma. Antropológiai írások. 194-226. Budapest: Osiris Kiadó.

2001c Mély játék: jegyzetek a bali kakasviadalról. In Geertz, Clifford: Az értelmezés hatalma. Antropológiai írások. 144-193. Budapest: Osiris Kiadó.

\section{HARRIS, MARVIN}

2001 The Rise of Anthropological Theory. A History of Theories of Culture. Updated Edition. Walnut Creek: Altamira Press.

HELM, ASA A.

2001 Franz Boas and Bronislaw Malinowski: A Contrast, Comparison, and Analysis. Lambda Alpha Journal 31:38-47.

HOLLÓS MARIDA

1995 Bevezetés a kulturális antropológiába. Budapest: ELTE-BTK Kulturális Antropológiai Szakcsoport.

INGOLD, TIM

2007 Anthropology is not Ethnography. Proceedings of the British Academy 154: 69-92. http://dx.doi.org/10.5871/bacad/9780197264355.003.0003

ISPÁN ÁGOTA - MAGYAR ZOLTÁN - MÉSZÁROS CSABA - VARGYAS GÁBOR SZERK.

2016 Ethno-lore, A Magyar Tudományos Akadémia Bölcsészettudományi Kutatóközpont Néprajztudományi Intézetének Évkönyve XXXIII, Budapest: MTA BTK NI.

2017 Ethno-lore, A Magyar Tudományos Akadémia Bölcsészettudományi Kutatóközpont Néprajztudományi Intézetének Évkönyve XXXIV, Budapest: MTA BTK NI. 


\section{KASCHUBA, WOLFGANG}

2004 Bevezetés az európai etnológiába. Debrecen - Miskolc: Csokonai Kiadó - Miskolci Egyetem Kulturális és Vizuális Antropológiai Tanszék.

KEYES, CHARLES F.

2002 Weber and Anthropology. Annual Review of Anthropology 31:233-255. https://doi.org/10.1146/annurev.anthro.31.040402.085332

KISDI BARBARA

2012 A kulturális antropológia története, elméletei és módszerei. Egyetemi jegyzet. Budapest: Pázmány Péter Katolikus Egyetem.

KROEBER, ALFRED. L.

1943 Franz Boas: The Man. American Anthropological Association. /Memoirs 61./

KROEBER, ALFRED L. - KLUCKHOHN, CLYDE

1952 Culture: A Critical Review of Concepts and Definitions. Cambridge, MA: Peabody Museum.

KROEBER, ALFRED L. - PARSONS, TALCOTT

1994 [1958] A kultúra és a társadalmi rendszer fogalma. Replika 14-15:236-238.

KUNT ERNŐ

2003 Az antropológia keresése. Budapest: L'Harmattan.

LAJOS VERONIKA

2016 Részvétel és együttmúködés. Fogalmak, dilemmák és értelmezések. Replika 100:23-40.

LASSITER, LUKE ERIC

2005 The Chicago Guide to Collaborative Ethnography. Chicago: The University of Chicago Press. https://doi.org/10.7208/chicago/9780226467016.001.0001

LEGRADY, GEORGE

1996 Interfész metaforák és új narratívák az interaktív médiában. In A felfedezés előtti pillanat.

Nemzetközi szimpózion az elfelejtett és előre nem látható médiatechnológiáról és médiamúvészetről. Műcsarnok, Budapest, 1996 jan 20 - feb 25. Internetcím: http://www.c3.hu/scca/butterfly/Legrady/synopsishu.html (Letöltés: 2019. július 19.)

LOWIE, ROBERT H.

1947 Biographical Memoir of Franz Boas 1858-1942. National Academy of Sciences of the United States of America. /Biographical Memoirs, Vol. 24./

\section{MALINOWSKI, BRONISLAW}

1931 Culture. In Encyclopedia of the Social Sciences, 4. köt. Seligman, Edwin R. A., editor-in-chief. 621-646. New York: Macmillan.

1939 The Group and the Individual in Functional Analysis. American Journal of Sociology 44 (6): 938-964. https://doi.org/10.1086/218181

1997 [1939] A csoport és az egyén a funkcionális elemzésben. In Mérföldkövek a kulturális antropológiában. Bohannan, Paul - Glazer, Mark, szerk. 379-405. Budapest: Panem.

2000 [1922] A nyugat-csendes-óceáni térség argonautái. Bevezetés: a kutatás tárgya, módszere és alkalmazási területe. Café Bábel 36 (Sziget): 43-57.

2001 [1989] Napló, a szó szoros értelmében. Café Bábel 41 (Napló): 81-93.

MARCUS, GEORGE E.

1995 Ethnography in/of the World System. The Emergence of Multi-Sited Ethnography. Annual Review of Anthropology 24:95-117. https://doi.org/10.1146/annurev.an.24.100195.000523

MÁRKUS GYÖRGY

1992 Kultúra és modernitás. Budapest: Lukács Archívum - T-Twins.

NAGY KÁROLY ZSOLT

2015 Ösvény a dzsungelben. Replika 90-91: 39-56. 
2018 Interaktív etnográfia: Néprajzi kutatás interfészek közti terepen. In A humán tudományok és a gépi intelligencia. Tolcsvai Nagy Gábor, szerk. 92-126. Budapest: Gondolat Kiadó.

\section{NIEDERMÜLLER PÉTER}

2005 Az antropológia metamorfózisai: perspektívák a (késő) modern társadalom kutatásában. Tabula 8(1):3-18.

\section{N. KOVÁCS TÍMEA}

1999 Kultúra - szöveg - reprezentáció: kulturális antropológia és irodalomtudomány. Helikon 65(4):479-493.

2007 A kultúra metaforái. Tabula 10(2):221-235.

ORTUTAY GYULA, FŐSZERK.

1980 Magyar Néprajzi Lexikon. Harmadik kötet, K-Né. Budapest: Akadémiai Kiadó.

\section{PAERREGAARD, KARSTEN}

2002 The resonance of fieldwork. Ethnographers, informants and the creation of anthropological knowledge. Social Anthropology 10(3):319-334. https://doi.org/10.1111/j.1469-8676.2002.tboo062.x

\section{RICOEUR, PAUL}

2001 A szöveg mint modell: a hermeneutikai megértés. Lettre 42, [online] Internetcím: http://epa.oszk.hu/00000/00012/00026/ricoeur.htm (Letöltés: 2019. július 16.)

RUBY, JAY

1980 Franz Boas and Early Camera Study of Behavior. Kinesics Report, 7-16.

SELIGMAN, BRENDA, ED.

1951 Notes and Queries on Anthropology. London: Routledge and Kegan Paul LTD

STOCKING, GEORGE W., JR.

1966 Franz Boas and the Culture Concept in Historical Perspective. American Anthropologist 68(4):867-882. https://doi.org/10.1525/aa.1966.68.4.02a00010

SYLVAIN, RENÉE

1996 Malinowski the Modern Other: An Indirect Evaluation of Postmodernism. Anthropologica 38(1):21-45. https://doi.org/10.2307/25605818

TYLOR, EDWARD BURNETT

1920 Primitive Culture. London: John Murray.

VÖRÖS MIKLÓS - FRIDA BALÁZS

$2006 \mathrm{Az}$ antropológiai résztvevő megfigyelés története. In Településkutatás II. Letenyei László, szerk. 395-416. Budapest: L’Harmattan - Ráció Kiadó.

WEBER, MAX

1967 Gazdaság és társadalom. Budapest: Közgazdasági és Jogi Kiadó.

WILLIAMS, VERNON J., JR.

1998 Franz Boas Paradox and the African American Intelligentsia. In African Americans and Jews in the Twentieth Century: Studies in Convergence and Conflict. Franklin Vincent P., ed. 54-86. Columbia: University of Missouri Press.

YENGOYAN, ARAM A.

1986 Theory in Anthropology: On the Demise of the Concept of Culture. Comparative Studies in Society and History 28(2):368-374. 